\title{
Abrupt sea surface pH change at the end of the Younger Dryas in the central sub-equatorial Pacific inferred from boron isotope abundance in corals (Porites)
}

\author{
E. Douville ${ }^{1}$, M. Paterne ${ }^{1}$, G. Cabioch ${ }^{2}$, P. Louvat $^{3}$, J. Gaillardet ${ }^{3}$, A. Juillet-Leclerc ${ }^{1}$, and L. Ayliffe ${ }^{4}$ \\ ${ }^{1}$ Laboratoire des Sciences du Climat et de l'Environnement, Institut Pierre Simon Laplace (LSCE/IPSL) Domaine du CNRS, \\ UMR 8212, Av. de la Terrasse, 91198 Gif/Yvette, France \\ ${ }_{2}^{2}$ Institut de Recherche pour le Développement (IRD), UMR IPSL/LOCEAN, UPMC/CNRS/IRD/MNHN, 32 avenue Henri \\ Varagnat, 93143 Bondy CEDEX, France \\ ${ }^{3}$ Institut Physique du Globe de Paris (IPG-Paris), Laboratoire de Géochimie et de Cosmochimie, Place Jussieu, \\ 75252 Paris, France \\ ${ }^{4}$ Research School of Earth Sciences, Australian National University, ACT 0200, Canberra, Australia
}

Received: 24 February 2010 - Published in Biogeosciences Discuss.: 18 March 2010

Revised: 6 July 2010 - Accepted: 20 July 2010 - Published: 16 August 2010

\begin{abstract}
The " $\delta{ }^{11} \mathrm{~B}-\mathrm{pH}$ " technique was applied to modern and ancient corals Porites from the sub-equatorial Pacific areas (Tahiti and Marquesas) spanning a time interval from 0 to 20.720 calendar years to determine the amplitude of $\mathrm{pH}$ changes between the Last Glacial Period and the Holocene. Boron isotopes were measured by MultiCollector - Inductively Coupled Plasma Mass Spectrometry (MC-ICPMS) with an external reproducibility of $0.25 \%$, allowing a precision of about $\pm 0.03 \mathrm{pH}$-units for $\mathrm{pH}$ values between 8 and 8.3. The boron concentration [B] and isotopic composition of modern samples indicate that the temperature strongly controls the partition coefficient $\mathrm{K}_{D}$ for different aragonite species. Modern coral $\delta^{11} \mathrm{~B}$ values and the reconstructed sea surface $\mathrm{pH}$ values for different Pacific areas match the measured $\mathrm{pH}$ expressed on the seawater scale and confirm the calculation parameters that were previously determined by laboratory calibration exercises. Most ancient sea surface $\mathrm{pH}$ reconstructions near Marquesas are higher than modern values. These values range between 8.19 and 8.27 for the Holocene and reached 8.30 at the end of the last glacial period $(20.7 \mathrm{kyr} B \mathrm{P})$. At the end of the Younger Dryas (11.50 $\pm 0.1 \mathrm{kyr} B \mathrm{P})$, the central sub-equatorial Pacific experienced a dramatic drop of up to $0.2 \mathrm{pH}$-units from the average $\mathrm{pH}$ of 8.2 before and after this short event. Using the marine carbonate algorithms, we recalculated the aqueous $p \mathrm{CO}_{2}$ to be $440 \pm 25 \mathrm{ppmV}$ at around $11.5 \mathrm{kyr} \mathrm{BP}$ for corals at Marquesas and $\sim 500 \mathrm{ppmV}$ near Tahiti where it
\end{abstract}

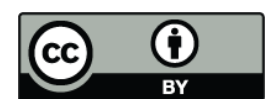

Correspondence to: E. Douville (eric.douville@1sce.ipsl.fr) was assumed that $p \mathrm{CO}_{2}$ in the atmosphere was $250 \mathrm{ppmV}$. Throughout the Holocene, the difference in $p \mathrm{CO}_{2}$ between the ocean and the atmosphere at Marquesas $\left(\Delta p \mathrm{CO}_{2}\right)$ indicates that the surface waters behave as a moderate $\mathrm{CO}_{2}$ sink or source ( -53 to $20 \mathrm{ppmV}$ ) during El Niño-like conditions. By contrast, during the last glacial/interglacial transition, this area was a marked source of $\mathrm{CO}_{2}$ (21 to $92 \mathrm{ppmV}$ ) for the atmosphere, highlighting predominant La Niña-like conditions. Such conditions were particularly pronounced at the end of the Younger Dryas with a large amount of $\mathrm{CO}_{2}$ released with $\Delta p \mathrm{CO}_{2}$ of $+185 \pm 25 \mathrm{ppmV}$. This last finding provides further evidence of the marked changes in the surface water $\mathrm{pH}$ and temperature in the equatorial Pacific at the Younger Dryas-Holocene transition and the strong impact of oceanic dynamic on the atmospheric $\mathrm{CO}_{2}$ content.

\section{Introduction}

The acidity of the ocean surface is increasing because of anthropogenic emission of $\mathrm{CO}_{2}$ into the atmosphere. This increase may have severe consequences for those organisms which build their external skeleton out of calcium carbonate $\left(\mathrm{CaCO}_{3}\right)($ Orr et al., 2005). During the last 200 years, roughly fifty percent of the anthropogenic $\mathrm{CO}_{2}$ (IPCC, 2005) contributed to the acidification of the superficial ocean by $0.1 \mathrm{pH}$-units. Models suggest that the sea surface $\mathrm{pH}$ could drop by $\sim 0.4$ units by the year 2100 if the present-day trend of carbon dioxide increase continues (Caldeira and Wickett, 2003). Today, the oceanic sources and sinks of $\mathrm{CO}_{2}$ show a high degree of spatial and annual to inter-annual

Published by Copernicus Publications on behalf of the European Geosciences Union. 


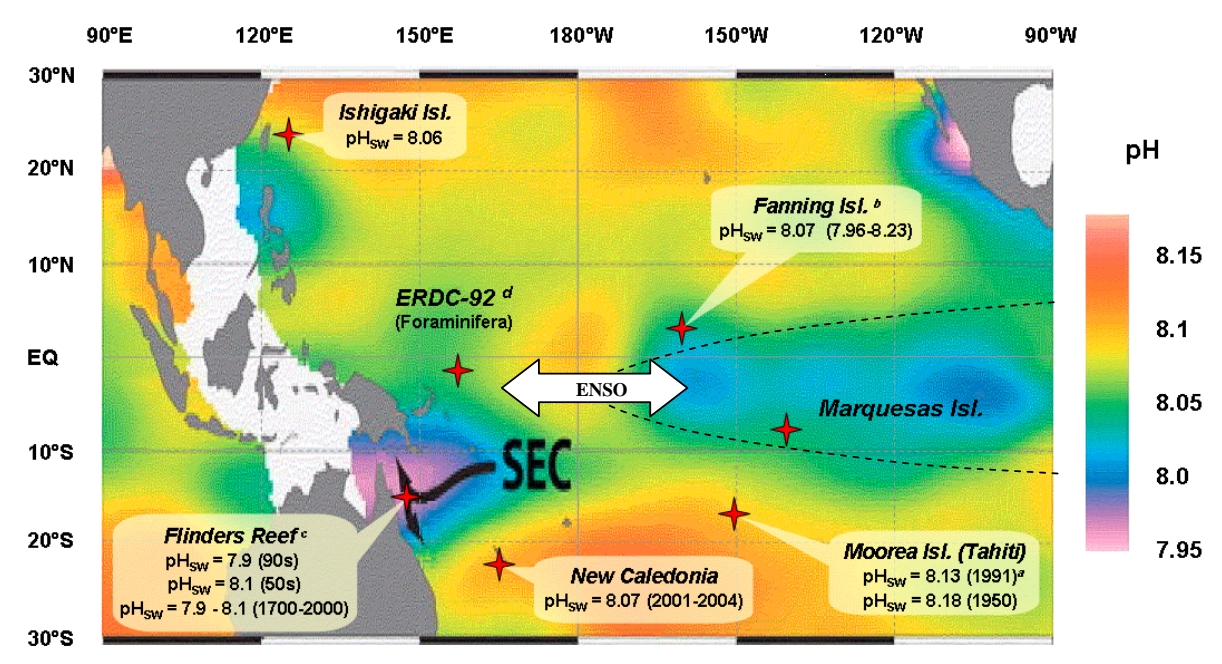

Fig. 1. Geographical locations of the study sites, including Moorea (close to Tahiti), Marquesas, Ishigaki, New Caledonia and the Fanning Islands. The location of the ERDC-92 box core (Palmer and Pearson, 2003) is also shown. The sea surface $\mathrm{pH}$ from modern corals are plotted on a seawater scale $\mathrm{pH}$ map modified from Pelejero et al. (2005). The $\delta^{11} \mathrm{~B}$ data of corals: (a) Gaillardet and Allègre, 1995; (b) Hemming et al., 1998; (c) Pelejero et al., 2005; the foraminifera $\delta^{11} \mathrm{~B}$ data: (d) Palmer and Pearson, 2003.

variability. For instance, the wind is strengthening, and uptake of $\mathrm{CO}_{2}$ in the Southern Ocean is reduced (Le Quéré et al., 2007). Changes in the marine biological pump control carbon removal from the upper ocean into the deep ocean (McGillicuddy et al., 2007). Changes have taken place in the oceanic circulation (Feely et al., 1999; Inoue et al., 2001), and these changes may counteract the anthropogenic acidification of the ocean. In the past, the atmospheric $p \mathrm{CO}_{2}$ changed by $\sim 80$ to $100 \mathrm{ppmV}$ between glacial and interglacial periods (Hönisch and Hemming, 2005; Hönisch et al., 2009; Monnin et al., 2001, 2004; Petit et al., 1999). Those variations are commonly ascribed to changes in the oceanic uptake of $\mathrm{CO}_{2}$ because the ocean is the largest carbon reservoir in the atmosphere-hydrosphere-biosphere system. However, the $\mathrm{CO}_{2}$ exchange and related mechanisms have not yet been fully understood and quantified (Archer et al., 2000; Kohfeld et al., 2005; Sigman and Boyle, 2000). Quantifying changes in the oceanic $p \mathrm{CO}_{2}$ over the centennial and millennial time scales will elucidate the role of the oceanic carbon cycle and the links between the oceanic and atmospheric changes of $p \mathrm{CO}_{2}$ and their consequences on ecosystems.

Ocean acidification and past sea surface $\mathrm{pH}$ or $p \mathrm{CO}_{2}$ may be deduced from the boron isotopic composition $\left(\delta^{11} \mathrm{~B}\right)$ of biogenic carbonates (Hemming and Hanson, 1992; Spivack et al., 1993). During the past decade, numerous studies evaluated the " ${ }^{11} \mathrm{~B}-\mathrm{pH}$ " relationship using experimental studies or laboratory cultures of foraminifera and corals (Hemming et al., 1995; Hönisch et al., 2004; Reynaud et al., 2004; Sanyal et al., 1996, 2000). Only a few studies based on tropical corals focused on the past hundreds or thousands of years. These first studies investigated the western Pacific Ocean (Pelejero et al., 2005; Wei et al., 2009) and more recently the South China Sea (Liu et al., 2009). These studies revealed pronounced sea surface $\mathrm{pH}$ changes by $0.2-0.3$ during the Holocene. These changes were strongly controlled by climate (monsoon) or oceanographic patterns (Pacific Decadal Oscillation).

First we describe in detail the modern "pH - Sea Surface Temperature" relationships for surface waters of the subEquatorial Pacific Ocean and the protocols used here to reconstruct the $\mathrm{pH}$ and $p \mathrm{CO}_{2}$ properties of surface waters. We also present the $\delta^{11} \mathrm{~B}-\mathrm{pH}$ relationship and partition coefficient for boron $K_{\mathrm{D}}$ obtained from modern Porites collected in tropical areas of various sea surface temperatures (SSTs). Then, we use the derived relationships to investigate ancient corals recovered from drowned reefs off the Marquesas and from modern reefs near the Tahiti Islands in the central equatorial Pacific (Fig. 1) to reconstruct past $\mathrm{pH}$, SST and $p \mathrm{CO}_{2}$ levels of these areas. These new results are compared to previous results from modern or ancient corals of the genera Acropora and Porites (Gaillardet and Allègre, 1995) and from planktonic foraminifera (Palmer and Pearson, 2003). The deduced changes in the sea surface $\mathrm{pH}$ and SST are evaluated against oceanographic patterns, and the estimated oceanic $p \mathrm{CO}_{2}$ values are compared to atmospheric values measured in Antarctic ice cores (Monnin et al., 2001, 2004).

\section{Hydrological setting of the central tropical Pacific Ocean: "pH-SST" relationships}

The $\mathrm{pH}$ and SST data show that in the modern equatorial Pacific, the sea surface $\mathrm{pH}$ and SST between $5^{\circ} \mathrm{S}$ and $20^{\circ} \mathrm{S}$ are highly negatively correlated (Fig. 2), data from http://www.nodc.noaa.gov/OC5/ SELECT/dbsearch/dbsearch.html) (Lefèvre et al., 1994). 
a)

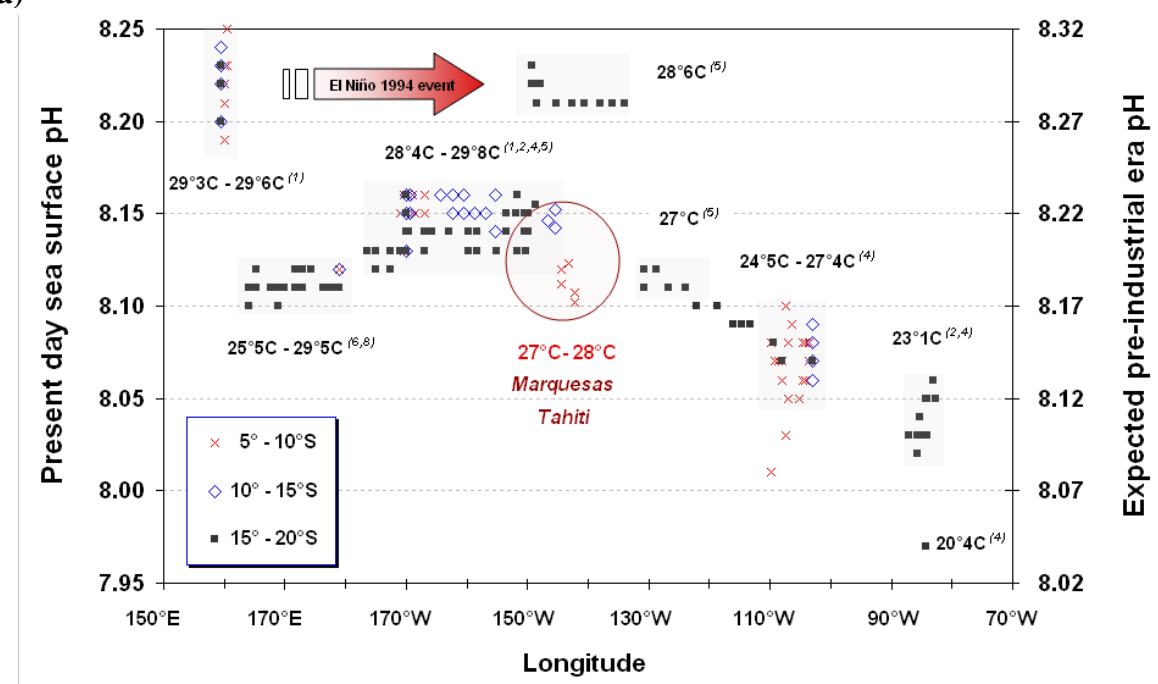

b)

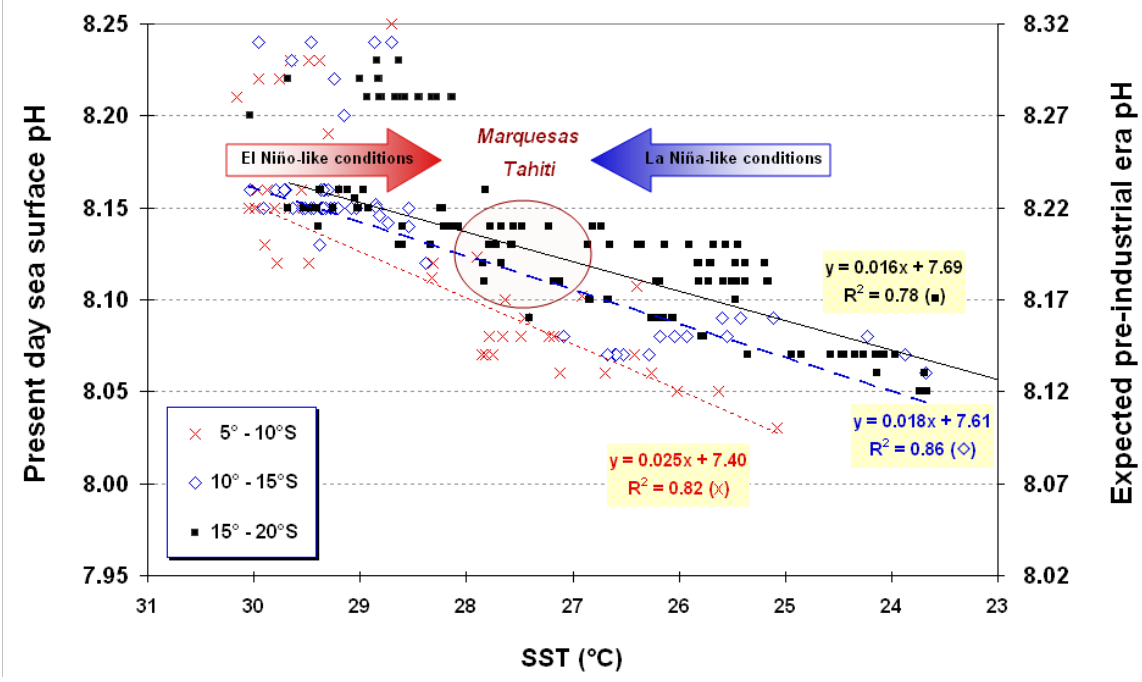

Fig. 2. (a) The present day sea surface $\mathrm{pH}$ in the sub-Equatorial Pacific Ocean as function of the geographical location (left axe). $0.07 \mathrm{pH}-$ units are added to the present day $\mathrm{pH}$ on the pre-industrial era $\mathrm{pH}$ axe (see text). The month (values in parenthesis) of the water sampling and the averaged SSTs are also indicated. (b) Sea surface $\mathrm{pH}$ in the sub-Equatorial Pacific Ocean plotted against SST between $150^{\circ} \mathrm{E}$ and $80^{\circ} \mathrm{W}$. Similar pH-SST correlations were observed for surface waters between $80^{\circ} \mathrm{W}$ and $170^{\circ} \mathrm{W}$ at three different ranges of latitude (sources from http://www.nodc.noaa.gov/OC5/SELECT/dbsearch/dbsearch.html; measurement years: 1980-1998; depths: 0-50 m).

This correlation is especially strong between $80^{\circ} \mathrm{W}$ and $170^{\circ} \mathrm{W}$ because of the cold and $\mathrm{CO}_{2}$-rich waters coming from the major deep water upwelling along the eastern coasts of the sub-Equatorial Pacific Ocean. In the eastern Pacific, the nutrient-rich surface waters are characterised by low $\mathrm{pH}$ and cool SST (Fig. 2a). The pH ranges from $\sim 7.98$ to about 8.01-8.06, as reported as present day pH (Fig. 2a, left axis), and the SST varies from $20.4{ }^{\circ} \mathrm{C}$ to $23.1^{\circ} \mathrm{C}$. At latitudes between $15^{\circ} \mathrm{S}$ and $20^{\circ} \mathrm{S}$, the $\mathrm{pH}$ increases slightly by about $0.05 \mathrm{pH}$-units, and the SST increases by $3{ }^{\circ} \mathrm{C}$ from $80^{\circ} \mathrm{W}$ to $170^{\circ} \mathrm{W}$. The increase is more than $0.07 \mathrm{pH}$-units between $5^{\circ} \mathrm{S}$ and $10^{\circ} \mathrm{S}$ (Fig. 2b). In the western Pacific, high $\mathrm{pH}$ values of $8.22 \pm 0.03$ and warm SSTs are observed during the boreal summer. During the boreal winter, the $\mathrm{pH}$ drops by $0.1 \mathrm{pH}$-unit. The SSTs are uniformly around $29.5^{\circ} \mathrm{C}$ between $5^{\circ} \mathrm{S}$ and $15^{\circ} \mathrm{S}$ and lower by about $4^{\circ} \mathrm{C}$ between $15^{\circ} \mathrm{S}$ and $20^{\circ} \mathrm{S}$. In the central Pacific between $130^{\circ} \mathrm{W}$ and $150^{\circ} \mathrm{W}$ and at latitudes higher than $15^{\circ} \mathrm{S}$, warm surface waters with a SST of $28.6^{\circ} \mathrm{C}$ and a $\mathrm{pH}$ of $\sim 8.22$ were observed during 1994, an El Niño year. These waters show pH-SST properties similar to those of the western Pacific surface waters (Fig. 2).

Most present day $\mathrm{pH}$ values for Marquesas and Tahiti (5$17^{\circ} \mathrm{S}$ ) between $130^{\circ} \mathrm{W}$ and $150^{\circ} \mathrm{W}$ range from 8.10 to 8.15 (Fig. 2). This east-west pH-SSTs pattern corresponds to the well-known seasonal variation of the zonal distribution of 
water masses along the equator. This pattern is modified by changes in the wind strength. During El Niño years, westward water transport through the South Equatorial Current SEC decreases in the central Pacific because of eastward transport of warmer water from the western Pacific (Taft and Kessler, 1991). The sea surface $\mathrm{pH}$ increases under these conditions. When strong easterlies return, the westward SEC flow increases, and the equatorial thermocline shoals and favours contribution of more $\mathrm{CO}_{2}$-rich waters. Consequently, during La Niña-like conditions, more acidic cold waters are advected from the east toward the central Pacific (Taft and Kessler, 1991).

\section{Materials and methods}

\subsection{Geographical setting and regional modern SST}

The " ${ }^{11} \mathrm{~B}-\mathrm{pH}$ " indicator was applied to modern Porites collected from New Caledonia (2001-2004), Moorea (1950) and Ishigaki Islands (Fig. 1). The New Caledonia sample used in this paper comes from outside the lagoon on the upper part of the barrier reef slope. This site is called Fausse passe d'Uitoé. The SST was measured at this site every month since 2000 and had a mean value of $24.4 \pm 1.9^{\circ} \mathrm{C}$ (Table 1). The coral skeleton spans the period from 2001-2004. Porites from Ishigaki Island is the coral reference material JCp-1 prepared by the Geological Survey of Japan (Inoue et al., 2004). The regional SST over the last two decades in this area is close to $26.1 \pm 2.1^{\circ} \mathrm{C}$. The average SST of a sample from Moorea (MOO3A-1-02) was $27.1 \pm 0.5^{\circ} \mathrm{C}$ (Boiseau, 1998). Another modern sample is COM 3 from the Red Sea. This sample grew at annually averaged SST of $22.5 \pm 1.5^{\circ} \mathrm{C}$ (Gertman and Brenner, 2004; Heiss et al., 1999). According to modern observations (http://www.nodc.noaa.gov) (Henin, 1999), the Marquesas area has a mean annual SST of $28 \pm 1^{\circ} \mathrm{C}$. The ancient Porites samples studied here were collected from submerged reefs off the Marquesas and Tahiti Islands in the Equatorial Pacific. Coral ages, which span from $20.72 \pm 0.20 \mathrm{kyr}$ BP to $0.25 \pm 0.03 \mathrm{kyr} \mathrm{BP}$, were obtained by mass spectrometric U-Th dating (Paterne et al., 2004; Cabioch et al., 2008).

\subsection{Chemical preparation}

The mean annual growth bands of Porites are about $10 \mathrm{~mm}$ in our samples. About $400 \mathrm{mg}$ of the coral skeleton were cut along the growth axis systematically. Each of these samples represents one or two years. It is most important to carefully collect a piece of coral integrating both low and high density bands in order to smooth out the effect of seasonal $\mathrm{pH}$ changes and to keep always the same sampling strategy. The coral fragments were crushed in an agate mortar, and the resulting carbonate powder was washed three times with ultra-pure water in an ultrasound bath (Gaillardet and
Allègre, 1995). Then, the powder was dissolved in dilute ultrapure Merck's $1 \mathrm{~N} \mathrm{HNO}_{3}$ before chemical purification. The solutions were purified on the anion exchange resin Amberlite IRA 743 using the batch method developed by Lécuyer et al. (2002). In 50ml polypropylene corning centrifuge tubes, the solutions were neutralised to a $\mathrm{pH}$ of 7-8. Resin, previously cleaned using $4 \mathrm{~N} \mathrm{HNO}_{3}$, was added in sufficient quantity $(500 \mathrm{mg}$ ) to extract $100 \%$ of boron from solution for each standard and sample. The tubes, up to 25 including samples and standards, were shaken for more than four hours before the resin was rinsed three times with MQ water. Then, boron was eluted by three successive volumes of $5 \mathrm{ml}$ of $0.1 \mathrm{~N} \mathrm{HNO}_{3}$. Extraction yields of close to $100 \%$ and accurate purification (level of residual $\mathrm{Ca}$ and major cations) were verified for each standard or sample by Inductively Coupled Plasma - Quadrupole Mass Spectrometry (ICP-QMS). Finally, the boron concentration was adjusted to $200 \mathrm{ppb}$ in $2 \%$ nitric acid for MC-ICPMS analyses.

\subsection{Boron isotope measurements}

The boron isotope composition was determined with doublefocusing sector-field multi-collector inductively coupled plasma mass spectrometers (MC-ICPMS Neptune of ThermoFisher Scientific) both in the Advanced Mass Spectrometry Laboratory of Thermo Fisher Scientific in Bremen (Germany) and at the Institut de Physique du Globe in Paris (France). Common introduction in Bremen was by a quartz double-pass spray chamber, and in Paris we used a direct injection high efficiency nebuliser (d-DIHEN). Mass drift of the ${ }^{11} \mathrm{~B} /{ }^{10} \mathrm{~B}$ ratio with time was systemically controlled by standard-sample bracketing. Most of the $\delta^{11} \mathrm{~B}$ values presented here were determined using the direct injection technique, which allows a strong reduction of the analytical blank contributions. These contributions were lower than $0.5 \%$ o for each isotope with a rinse time of $3 \mathrm{~min}$ or less (Louvat et al., 2010). Using direct injection (d-DIHEN) and conventional introduction, comparison of repeated analyses for four different samples (DW1281c_78a1; DW1261_68a1; DW1281_75a2; MOO 3A-1-02) yields excellent agreement within the analytical uncertainty of $0.25 \%$ o given here (Fig. 3, Table 1). The reproducibility and accuracy of the ${ }^{11} \mathrm{~B} /{ }^{10} \mathrm{~B}$ ratios were calculated from repeated analyses of the boric acid standard NBS-951 and the North Atlantic Seawater Standard NASS-II. The measured external reproducibility of $0.25 \% \circ(2 \sigma)$ is similar to the reproducibility that was recently published for MC-ICPMS analyses by Neptune (Foster, 2008; Louvat et al., 2010). A mean $\delta^{11} \mathrm{~B}$ of $39.9 \%$ o $(n=20$, $2 \sigma$ ) was measured for NASS-II. This value is also within the external precision range of $39.7-40.2 \%$ previously published for thermal ionization mass spectrometry (TIMS) or MC-ICPMS measurements (Gaillardet and Allègre, 1995; Hemming and Hanson, 1992; Hönisch et al., 2004; Wei et al., 2009; Louvat et al., 2010). The external reproducibility of $0.25 \% \circ(2 \sigma)$ represents our analytical precision for 
Table 1. Isotopic composition of boron $\delta^{11} \mathrm{~B}(\% \circ)$ and boron concentrations measured for coral and seawater samples. The $\Delta p \mathrm{CO}_{2}$ calculation is detailed in the text. The previously published $\delta^{11} \mathrm{~B}$ data for corals includes

a Gaillardet and Allègre, 1995;

${ }^{\mathrm{b}}$ Hemming et al., 1998; and

c Pelejero et al., 2005.

The ${ }^{230} \mathrm{Th} / \mathrm{U}$ ages of the corals from Tahiti and Marquesas are from Bard et al. (1996), Cabioch et al. (2008), Paterne et al. (2004).

$*{ }^{230} \mathrm{Th} / \mathrm{U}$ age of the sample Ta-3 is the former date published by Gaillardet and Allègre (1995).

SST sources: (http://www.nodc.noaa.gov (Boiseau, 1998; Gertman and Brenner, 2004; Heiss et al., 1999; Henin and Cresswell, 2005).

\begin{tabular}{|c|c|c|c|c|c|c|c|c|c|}
\hline Samples, mean SST & $\begin{array}{l}{ }^{230} \mathrm{Th} / \mathrm{U} \\
\text { age cal. }\end{array}$ & $\begin{array}{l}\text { Boron } \\
(\mathrm{ppm})\end{array}$ & $\begin{array}{l}\text { LSCE } \\
\text { number }\end{array}$ & $\begin{array}{l}\delta^{11} \mathrm{~B}(\% o) \\
(2 \sigma, n)\end{array}$ & $\begin{array}{l}\text { Salinity } \\
\text { (Sea level) }\end{array}$ & $\begin{array}{l}A_{\mathrm{k}} \\
\mu \mathrm{M}\end{array}$ & $\begin{array}{l}\mathrm{pH} \\
( \pm 0.03)\end{array}$ & $\begin{array}{l}p \mathrm{CO}_{2} \\
(\mathrm{ppmV})\end{array}$ & $\begin{array}{l}\Delta p \mathrm{CO}_{2} \\
(\mathrm{ppmV})\end{array}$ \\
\hline \multicolumn{10}{|c|}{ Marquesas Islands, $28 \pm 1.0^{\circ} \mathrm{C}$} \\
\hline Nuku Hiva DR6(1) & $250 \pm 30$ & 40.0 & $\mathrm{~B} 33^{\mathrm{di}}$ & $26.2 \pm 0.2(2)$ & 35.6 & 2401 & 8.21 & 264 & -16 \\
\hline \multirow[t]{2}{*}{ DW1281c _78a1 } & $3230 \pm 30$ & 63.2 & B01, 02, 03, 04 & $26.5 \pm 0.2(6)$ & 35.6 & 2401 & 8.25 & 238 & -36 \\
\hline & & & $\mathrm{B} 20^{\mathrm{di}}$ & $26.8 \pm 0.3(1)$ & 35.6 & 2401 & 8.27 & 221 & -53 \\
\hline \multirow[t]{2}{*}{ DW1261_68a1 } & $3260 \pm 30$ & 60.0 & $\mathrm{~B} 15,16$ & $26.3 \pm 0.3$ & 35.6 & 2401 & 8.22 & 260 & -14 \\
\hline & & & $\mathrm{B} 18^{\mathrm{di}}$ & $26.1 \pm 0.1$ & 35.6 & 2401 & 8.21 & 269 & -5 \\
\hline Eiao DR16(3) & $8^{\circ} 990 \pm 130$ & 37.4 & $\mathrm{~B} 31^{\mathrm{di}}$ & $26.0 \pm 0.3(2)$ & $35.9(-30 \mathrm{~m})$ & 2420 & 8.19 & 281 & 20 \\
\hline Eiao DR16(5) & $9^{\circ} 110 \pm 130$ & 53.4 & $\mathrm{~B} 32^{\mathrm{di}}$ & $26.3 \pm 0.5(2)$ & $35.9(-30 \mathrm{~m})$ & 2420 & 8.22 & 259 & -5 \\
\hline Eiao DR12(1) & $9^{\circ} 590 \pm 180$ & 43.5 & $\mathrm{~B} 30^{\mathrm{di}}$ & $26.2 \pm 0.2(3)$ & $35.9(-30 \mathrm{~m})$ & 2420 & 8.21 & 270 & 6 \\
\hline \multirow[t]{2}{*}{ DW1281_75a2 } & $11470 \pm 90$ & 45.3 & $\mathrm{~B} 13,14$ & $24.8 \pm 0.1$ & $36.2(-60 \mathrm{~m})$ & 2440 & 8.06 & 420 & 164 \\
\hline & & & B19 $9^{\text {di }}$ & $24.5 \pm 0.2(2)$ & $36.2(-60 \mathrm{~m})$ & 2440 & 8.02 & 464 & 209 \\
\hline Hiva Oa DR10(2) & $12420 \pm 100$ & 51.9 & $\mathrm{~B} 27^{\mathrm{di}}$ & $26.2 \pm 0.2(3)$ & $36.2(-65 \mathrm{~m})$ & 2443 & 8.21 & 273 & 34 \\
\hline Eiao DR11bis(4) & $13410 \pm 190$ & n.d. & $\mathrm{B} 53^{\mathrm{di}}$ & $25.6 \pm 0.3(1)$ & $36.3(-75 \mathrm{~m})$ & 2449 & 8.14 & 330 & 92 \\
\hline Eiao DR8(1) & $14560 \pm 180$ & 42.1 & $\mathrm{~B} 29^{\mathrm{di}}$ & $26.1 \pm 0.2(2)$ & $36.5(-90 \mathrm{~m})$ & 2459 & 8.19 & 284 & 49 \\
\hline Hiva Oa DR14bis(1) & $15450 \pm 150$ & 40.0 & $\mathrm{~B} 28^{\mathrm{di}}$ & $26.1 \pm 0.3(3)$ & $36.6(-105 \mathrm{~m})$ & 2469 & 8.20 & 281 & 57 \\
\hline Hiva Oa DR8bis(1) & $15460 \pm 110$ & 43.8 & $\mathrm{~B} 26^{\mathrm{di}}$ & $26.4 \pm 0.2(2)$ & $36.6(-105 \mathrm{~m})$ & 2469 & 8.23 & 256 & 33 \\
\hline Hiva Oa DR5 & $20720 \pm 200$ & 63.6 & $\mathrm{~B} 25^{\mathrm{di}}$ & $27.1 \pm 0.3(3)$ & $36.8(-125 \mathrm{~m})$ & 2482 & 8.30 & 209 & 21 \\
\hline \multicolumn{10}{|c|}{ Moorea-Tahiti Islands, $27.1 \pm 0.5^{\circ} \mathrm{C}$} \\
\hline \multicolumn{10}{|c|}{ Porites: } \\
\hline $\mathrm{COM} 2^{\mathrm{a}}$ & 1991(AD) & 51.0 & & $25.3 \pm 0.2(3)$ & 35.6 & 2401 & 8.13 & 340 & -15 \\
\hline \multirow[t]{2}{*}{ MOO 3A-1-02 } & $1950(\mathrm{AD})$ & 51.9 & $\mathrm{~B} 11,12$ & $25.8 \pm 0.2(3)$ & 35.6 & 2401 & 8.18 & 294 & -16 \\
\hline & & & $\mathrm{B} 17^{\mathrm{di}}$ & $25.8 \pm 0.2(3)$ & 35.6 & 2401 & 8.18 & 292 & -18 \\
\hline Ta P8-348 & $12910 \pm 30$ & n.d. & B56 $6^{\mathrm{di}}$ & $25.9 \pm 0.3(3)$ & $36.3(-75 \mathrm{~m})$ & 2449 & 8.19 & 287 & 53 \\
\hline Ta P8-353 & $13335 \pm 30$ & n.d. & $\mathrm{B} 57^{\mathrm{di}}$ & $26.6 \pm 0.2(3)$ & $36.3(-75 \mathrm{~m})$ & 2449 & 8.26 & 231 & -7 \\
\hline \multicolumn{10}{|c|}{ Acropora $^{\mathrm{a}}$ : } \\
\hline Ta-1 & $8520 \pm 40$ & 50.0 & & $25.7 \pm 0.3(2)$ & $35.9(-30 \mathrm{~m})$ & 2420 & 8.23 & 251 & -10 \\
\hline Ta-2 & $9260 \pm 50$ & 49.0 & & $25.4 \pm 0.2$ & $35.9(-30 \mathrm{~m})$ & 2420 & 8.21 & 273 & 12 \\
\hline Ta-3 & $9850^{*}$ & 51.0 & & $25.6 \pm 0.2(2)$ & $35.9(-30 \mathrm{~m})$ & 2420 & 8.22 & 259 & -4 \\
\hline Ta-4 & $10250 \pm 40$ & 52.0 & & $25.9 \pm 0.3(1)$ & $36.0(-40 \mathrm{~m})$ & 2427 & 8.25 & 237 & -30 \\
\hline Ta-5 & $10575 \pm 50$ & 41.0 & & $24.6 \pm 0.3(1)$ & $36.0(-45 \mathrm{~m})$ & 2430 & 8.11 & 357 & 91 \\
\hline Тa-6 & $10850 \pm 50$ & 50.0 & & $26.6 \pm 0.2(2)$ & $36.1(-50 \mathrm{~m})$ & 2433 & 8.32 & 196 & -69 \\
\hline Ta-7 & $11000 \pm 40$ & 50.0 & & $25.3 \pm 0.2(2)$ & $36.1(-50 \mathrm{~m})$ & 2433 & 8.19 & 290 & 26 \\
\hline Тa- 8 & $11280 \pm 30$ & 41.0 & & $24.4 \pm 0.2(3)$ & $36.1(-55 \mathrm{~m})$ & 2436 & 8.09 & 387 & 123 \\
\hline Ta-9 & $11495 \pm 30$ & 41.0 & & $23.6 \pm 0.2(3)$ & $36.2(-60 \mathrm{~m})$ & 2440 & 7.99 & 508 & 254 \\
\hline \multicolumn{10}{|c|}{ Ishigaki Island, $26.1 \pm 2.1^{\circ} \mathrm{C}$} \\
\hline Porites JCp-1 (standard) & modern & 47.7 & 9 samplings & $24.5 \pm 0.2(17)$ & 35 & & 8.06 & & \\
\hline \multicolumn{10}{|c|}{ New Caledonia, $24.4 \pm 1.9^{\circ} \mathrm{C}$} \\
\hline NC_a & 2001-2002 (AD) & 55.0 & $\mathrm{~B} 84^{\mathrm{di}}, 85^{\mathrm{di}}$ & $24.3 \pm 0.2(2)$ & 35 & & 8.04 & & \\
\hline NC_b & $2002-2003$ (AD) & 54.6 & $\mathrm{~B} 86^{\mathrm{di}}, 87^{\mathrm{di}}$ & $24.5 \pm 0.6(2)$ & 35 & & 8.06 & & \\
\hline NC_c & 2003-2004 (AD) & 54.4 & $\mathrm{~B} 89^{\mathrm{di}}, 90^{\mathrm{di}}, 91^{\mathrm{di}}, 92^{\mathrm{di}}$ & $24.8 \pm 0.5(4)$ & 35 & & 8.10 & & \\
\hline \multicolumn{10}{|c|}{$\operatorname{Red~Sea}^{\mathrm{a}}, 22.5 \pm 2.0^{\circ} \mathrm{C}$} \\
\hline COM3 & $1970-80(\mathrm{AD})$ & 57.0 & & $23.7 \pm 0.5(2)$ & 35 & & 7.98 & & \\
\hline \multicolumn{10}{|c|}{ Fanning Island ${ }^{\mathrm{b}}, 25-28^{\circ} \mathrm{C}$} \\
\hline \multirow[t]{2}{*}{ Porites Lobata } & mean & 50.5 & Seasonal & 24.8 & 35 & & 8.07 & & \\
\hline & Two year range & $46.1-53.9$ & microsamplings & $23.9-26.2$ & 35 & & $7.96-8.23$ & & \\
\hline \multicolumn{10}{|c|}{ Flinders Reef ${ }^{c}$} \\
\hline \multirow[t]{3}{*}{ FLO2A } & 1990s (AD) & - & & 23 & 35 & & $\sim 7.9$ & & \\
\hline & $1950 \mathrm{~s}(\mathrm{AD})$ & - & & 24.5 & 35 & & $\sim 8.1$ & & \\
\hline & $1700-2000(\mathrm{AD})$ & - & & $23.0-25.0$ & 35 & & $7.9-8.1$ & & \\
\hline
\end{tabular}




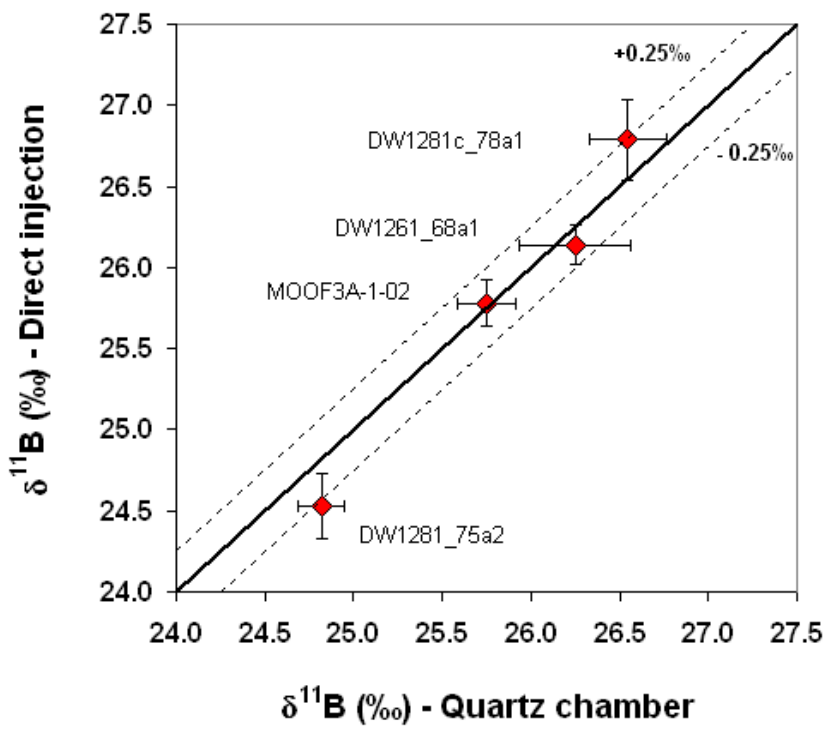

Fig. 3. Comparison of MC-ICPMS analyses using direct injection (d-DIHEN) and conventional introduction for Porites referenced DW1281c_78a1, DW1261_68a1, DW1281_75a2 and MOO3A-102. $\delta^{11} \mathrm{~B}$ results show an excellent agreement of the two introduction technique within the external reproducibility considered here of $\pm 0.25 \%$. Error bars are the standard deviation calculated from the "n" measurements for each sample (Table 1).

each of the analyzed samples. The boron isotopic composition of seawater $\left(\delta^{11} \mathrm{~B}_{\mathrm{SW}}\right)$ used for $\mathrm{pH}$ calculations was $39.9 \%$. Boron concentrations were measured with a precision of $\pm 3 \%(2 \sigma)$ by ICP-QMS (ThermoFisher X-series) at Laboratoire des Sciences du Climat et de l'Environnement (LSCE) in Gif-sur-Yvette (France).

\section{4 $\mathrm{pH}$ and $p \mathrm{CO}_{2}$ calculations for seawater}

The sea surface paleo-pH can be reliably reconstructed by measuring the boron isotopes in tropical corals. Two previous calibration exercises using laboratory-cultured corals (Acropora and Porites) demonstrate the validity of the technique and provide empirical calculation parameters (Hönisch et al., 2004; Reynaud et al., 2004). These pH calculations are based on isotopic fractionation by the coral of two boron species: borate ions $\mathrm{B}(\mathrm{OH})_{4}^{-}$and boric acid $\mathrm{B}(\mathrm{OH})_{3}$. The relative proportions of these species and their isotopic composition in seawater are $\mathrm{pH}-$ dependent (Hemming and Hanson, 1992; Vengosh et al., 1991). Thus borate ions $\mathrm{B}(\mathrm{OH})_{4}^{-}$ dissolved in seawater would be preferentially incorporated into the carbonate skeleton by substitution of bicarbonate ions (Hemming and Hanson, 1992). Consequently, the relationship (Eq. 1) between $\mathrm{pH}$ and $\delta^{11} \mathrm{~B}$ is as follows:

$$
\begin{aligned}
& \mathrm{pH}=p K_{\mathrm{B}}-\log \\
& \left(\frac{\delta^{11} \mathrm{~B}_{\mathrm{SW}}-\delta^{11} \mathrm{~B}_{\text {carbonate }}}{\alpha^{-1} \delta^{11} \mathrm{~B}_{\text {carbonate }}-\delta^{11} \mathrm{~B}_{\mathrm{SW}}+1000\left(\alpha^{-1}-1\right)}\right)
\end{aligned}
$$

where $p K_{\mathrm{B}}$ is the equilibrium constant between the boric acid $\mathrm{B}(\mathrm{OH})_{3}$ and the borate ions $\mathrm{B}(\mathrm{OH})_{4}^{-}$in seawater (Dickson, 1990). $\delta^{11} \mathrm{~B}_{\text {carbonate }}\left(\delta^{11} \mathrm{~B}\right)$ is the isotopic composition of boron measured here in Porites. $\delta^{11} \mathrm{~B}_{\mathrm{SW}}$ is the isotopic composition of boron measured for seawater. And the value $\alpha\left(\alpha_{4-3}\right)$ is the isotopic fractionation factor between the two boron bearing species in seawater (boric acid and borate ion) for the following equilibrium (Reaction R1):

$$
{ }^{11} \mathrm{~B}(\mathrm{OH})_{3}+{ }^{10} \mathrm{~B}(\mathrm{OH})_{4}^{-} \stackrel{\alpha_{3-4}}{\longleftrightarrow} \mathrm{B}(\mathrm{OH})_{3}+{ }^{11} \mathrm{~B}(\mathrm{OH})_{4}^{-}
$$

Factors such as temperature, salinity, light, food (Hönisch et al., 2004), and especially the coefficient $\alpha$ determine the uncertainties associated with calculating the $\mathrm{pH}$ (Pagani et al., 2005). Until recently, $\alpha$ was the subject of numerous empirical or theoretical studies with the goal of precisely determining its value. The following two major trends appear from these studies: (1) $\alpha \geq 0.980-0.981$ (Gaillardet and Allègre, 1995; Hemming et al., 1995; Hönisch et al., 2004, 2007; Kakihana et al., 1977; Palmer and Pearson, 2003; SanchezValle et al., 2005; Sanyal et al., 1996, 2000; Xiao et al., 2006) and (2) $\alpha \leq 0.974-0.976$ (Foster et al., 2008; Klochko et al., 2006; Lécuyer et al., 2002; Pagani et al., 2005; Zeebe, $2005)$. The first trend $(\alpha \geq 0.980-0.981)$ is usually applied today for paleo-reconstructions even though, today, the $\alpha$ value of 0.974 is considered as the unique and verified isotopic fractionation factor in seawater (Klochko et al., 2006). The calculated sea surface $\mathrm{pH}$ from our $\delta^{11} \mathrm{~B}$ data (described below) would range from 8.4 to 8.6 with this theoretical value. These values are 0.3 to $0.4 \mathrm{pH}$-units higher than the expected present day $\mathrm{pH}$. To reconstruct $\mathrm{pH}$ values that are more compatible with the seawater or total hydrogen ion $\mathrm{pH}$ scales, we use a value of the coefficient $\alpha$ of 0.981 (Kakihana et al., 1977). This value was empirically determined by calibration for both coral genera Acropora and Porites (Hönisch et al., 2004; Reynaud et al., 2004). These laboratory experiments reveal also a systematic $0.6 \delta^{11} \mathrm{~B}$ offset between these two coral types over the $\mathrm{pH}$ range from 7.7 to 8.2. These $\delta^{11} \mathrm{~B}$ offset may result in a systematic $\mathrm{pH}$ offset between the two genera of corals. This offset was taken into account by adding $0.6 \%$ o to the $\delta^{11} \mathrm{~B}$ values of each ancient Acropora sample from Tahiti for comparison with our Porites $\delta^{11} \mathrm{~B}$ values (Gaillardet and Allègre, 1995).

To estimate the oceanic $p \mathrm{CO}_{2}$ from the $\delta^{11} \mathrm{~B}-\mathrm{pH}$ values of the corals, we followed the procedure described by Hönisch and Hemming (2005). This procedure is based on the determination of two of the four parameters of the marine carbonate equilibrium $\left(p \mathrm{CO}_{2}, \Sigma \mathrm{CO}_{2}\right.$, alkalinity and $\left.\mathrm{pH}\right)$ in addition to Sea Surface Salinity (SSS) and SST. Using the National Oceanic and Atmospheric Administration (NOAA) data for modern water masses in the sub-Equatorial Pacific Ocean, we obtain a linear correlation between the total alkalinity $\left(A_{\mathrm{k}}\right)$ and the SSS of $\left(A_{\mathrm{k}}=0.0688 \cdot \mathrm{SSS}-0.0484 ; R^{2}=0.974\right.$; $n=233$ ). 
We hypothesise that the present-day " $A_{\mathrm{k}}-\mathrm{SSS}$ " relationship was also valid in the past. Past salinities can be estimated from sea-level changes through the past (Bard et al., 1996). For example, a reduction of $60 \mathrm{~m}$ occurred during the Younger Dryas (YD) over a mean oceanic depth of $3800 \mathrm{~m}$. This estimate takes into account the modern salinity near Tahiti and the Marquesas Islands of $35.6 \pm 1$ as a reference (Delcroix et al., 1996). From this calculation, the salinity in the past was about 36.2 in the central Pacific and about 34.8 in the eastern Pacific during the YD (Table 1). We consider today's mean seasonal salinity variability of \pm 1 (Delcroix et al., 1996) in the calculation. The oceanic $p \mathrm{CO}_{2}$ calculation was performed from $\mathrm{pH}$ and total alkalinity values listed in Table 1 using the guide to best practices for ocean $\mathrm{CO}_{2}$ measurements by Dickson et al. (2007) with $K_{1}$ and $K_{2}$ from Lueker et al. (2000), $K_{\mathrm{W}}$ from (Millero, 1995), $K_{0}$ from Weiss (1974) and $\mathrm{pH}$ values on the total hydrogen ion $\mathrm{pH}$ scale (close to the seawater one).

\section{Results and discussion}

To verify the reliability of $\mathrm{pH}$ reconstruction from boron isotopes in corals, we first analyzed the $\delta^{11} \mathrm{~B}$ and $\mathrm{pH}$ data for modern Porites samples collected from various areas and compared our results with the present day $\mathrm{pH}$ measured in the Pacific. Those areas cover a range of SST values and allow us to further elucidate the influence of the temperature on the incorporation of boron and its isotopic composition in corals. For each area, the measured or previously published values of $\delta^{11} \mathrm{~B}$ and [B] in Porites are evaluated against a theoretical curve that illustrates the preferential incorporation of borate ions in corals by substituting for the bicarbonate ions (Hemming and Hanson, 1992). This approach allows us to determine the various values of the partition coefficient $K_{\mathrm{D}}$ and to establish a link between the SST and $K_{\mathrm{D}}$. Similar exercises were done for the ancient corals from Marquesas and Tahiti to obtain information about the past SST. Finally, the changes in the $\mathrm{pH}$ and the $p \mathrm{CO}_{2}$ as a function of time will be discussed in the central sub-equatorial Pacific by using the results of the " ${ }^{11} \mathrm{~B}-\mathrm{pH}$ " calculation for both Porites near Marquesas (this study) and Acropora near Tahiti (Gaillardet and Allègre, 1995). This analysis takes into account the observed SST data.

\subsection{Reconstruction of the pH and SST from $\delta^{11} B$ and [B] data in modern Porites}

\subsection{1 $\mathrm{pH}$ deduced from $\delta^{11} \mathrm{~B}$ in modern Porites}

The mean $\delta^{11} \mathrm{~B}$ values measured in modern Porites (Table 1) were about $25.8 \pm 0.2 \%$ o $(n=6)$ for Moorea (1950 AD), $24.6 \pm 0.3 \%$ o $(n=8)$ for New Caledonia (2001-2004 AD) and $24.5 \pm 0.2 \%$ o $(n=17)$ for the Ishigaki Island (JCp-1). These values are similar to the modern value of $24.8 \%$ published for the Fanning Island (Hemming et al., 1998) and higher than the values of $23.6 \%$ and $23 \%$ found for the Red Sea (Gaillardet and Allègre, 1995) and Flinders Reef ( $\sim 1990$ AD) along the Great Barrier Reef (Pelejero et al., 2005), respectively. According to the regional SST and SSS of $35 \mathrm{psu}$, the deduced sea surface $\mathrm{pH}$ was 7.98 for the Red Sea, 8.06 for the Ishigaki area, 8.07 for Fanning Island, $8.07 \pm 0.3$ for New Caledonia and 8.13 and 8.18 for Moorea in $1991 \mathrm{AD}$ and $1950 \mathrm{AD}$, respectively. The $\delta^{11} \mathrm{~B}$ value for Moorea was higher by $+0.5 \%$ o than the previous measurement in 1991 (Gaillardet and Allègre, 1995). This change corresponds to the $\mathrm{pH}$ change of $0.05 \mathrm{pH}$-unit. These values from modern Porites off the Moorea match the $\mathrm{pH}$ values measured in this area (Fig. 2). The inter-decadal variability linked, for example, to the Pacific Decadal Oscillation (PDO), could explain the difference observed in the western Pacific (Pelejero et al., 2005), but this $\delta^{11} \mathrm{~B}$ change could also reflect the consequences of surface water acidification during the industrial era given our own recent description of the last century at Fiji (Douville et al., 2009). Finally, the pH values deduced from the modern Porites for various areas of the Pacific Ocean match well with the present day $\mathrm{pH}$ map (Fig. 1) that was calculated on the seawater scale. These results corroborate the analyses that were based on empirical $\alpha$ values and previous lab calibrations on the tropical coral Porites (Hönisch et al., 2004; Reynaud et al., 2004).

\subsubsection{SST and the partition constant $K_{D}$ for aragonite corals}

All of the $\delta^{11} \mathrm{~B}$ values versus [B] obtained here (Table 1) for modern Porites from Moorea, Ishigaki and New Caledonia Islands in the Pacific Ocean were compared to available published values for Moorea, Fanning Island and the Red Sea (Gaillardet and Allègre, 1995; Hemming et al., 1998) and plotted (Fig. 4a) to verify the model of a unique incorporation of boron (as borate ions) into the corals by substitution of bicarbonates ions (Hemming and Hanson, 1992; Sanyal et al., 2000; Yu and Elderfield, 2007; Foster, 2008). This model suggests that the $[\mathrm{B}]$ (or $\mathrm{B} / \mathrm{Ca}$ ) in corals increases together with the $\delta^{11} \mathrm{~B}$ and is controlled by the borate/bicarbonate abundance ratio in seawater according to the following relationship (Eq. 2):

$[\mathrm{B} / \mathrm{Ca}]_{\text {corals }}=K_{\mathrm{D}} \cdot\left[\mathrm{B}(\mathrm{OH})_{4}^{-} / \mathrm{HCO}_{3}^{-}\right]_{\text {seawater }}$

where $K_{\mathrm{D}}$ is the partition coefficient for boron. For various $\mathrm{pH}$ conditions, the theoretical $\delta^{11} \mathrm{~B}$ or $\left[\mathrm{B}(\mathrm{OH})_{4}^{-} / \mathrm{HCO}_{3}^{-}\right] \mathrm{ra}-$ tios for seawater and the $[\mathrm{B}]$ for corals can be calculated and plotted by setting a $K_{\mathrm{D}}$ value. This model curve can be directly compared and fitted to points that correspond to the $\delta^{11} \mathrm{~B}$ and the [B] values measured in corals for each studied area. Model curves were generated with empirical values of $\alpha=0.981$ (Kakihana et al., 1977), $\delta^{11} \mathrm{~B}_{\mathrm{SW}}=39.9 \%$ (this work) and $p K_{\mathrm{B}}=8.56$ (Dickson, 1990) at $28^{\circ} \mathrm{C}$ and 35 psu. Figure $4 \mathrm{a}$ does not validate the model for a one and unique partition coefficient $K_{\mathrm{D}}$ but shows scattered points that represent 
a)

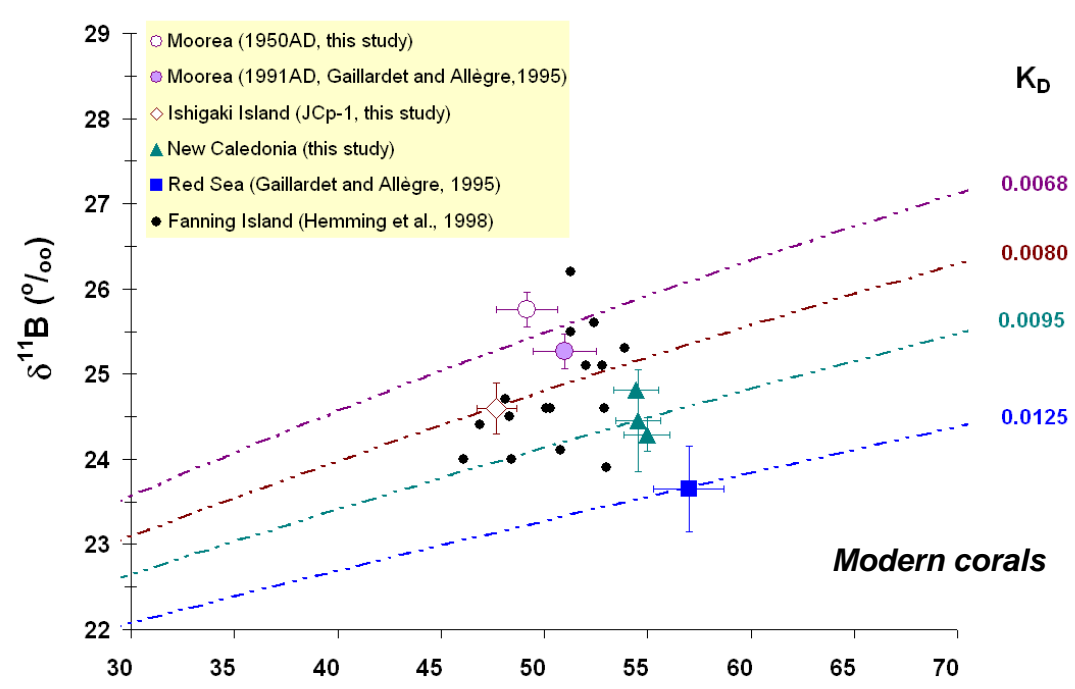

b)

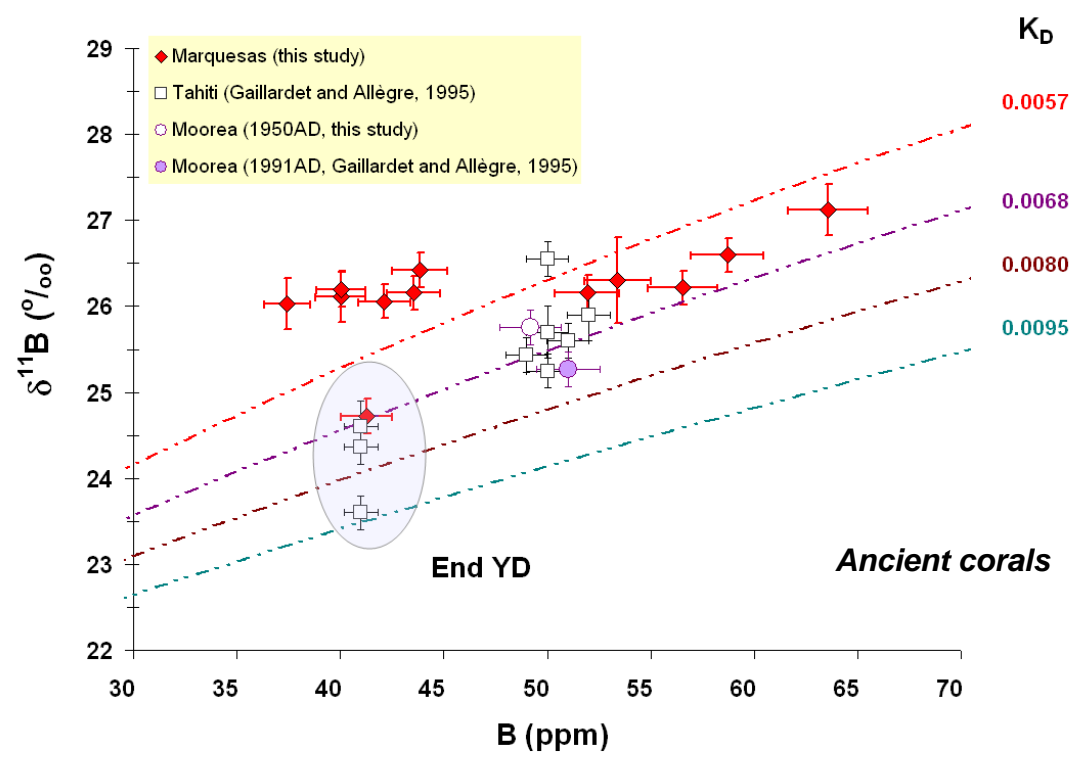

Fig. 4. The $\delta^{11} \mathrm{~B}$ values plotted against the boron concentrations (a) for modern Porites from various geographical areas and (b) for ancient Porites and Acropora near Marquesas and the Tahiti Islands. The theoretical curves for different partition coefficient $K_{\mathrm{D}}$ values were calculated assuming $T=28^{\circ} \mathrm{C} ; S=35 \%$; $\alpha=0.981$; and $\delta^{11} \mathrm{~B}_{\mathrm{SW}}=39.9 \%$ o. Seawater values used were $[\mathrm{B}]_{\text {seawater }}=416 \mu \mathrm{M}$ and $T \mathrm{CO} 2=2 \mathrm{mM}$.

various values of the partition coefficient $K_{\mathrm{D}}$ ranging between 0.0068 (Moorea) and 0.0125 (Red Sea). In contrast, a similar graph for ancient corals shows values better validating the model with average $K_{\mathrm{D}}$ values of 0.0057 and 0.0068 for the Marquesas and Tahiti samples, respectively (Fig. 4b). The highest values are observed for the corals that grew at the end the Younger Dryas with values up to 0.0095 (Tahiti).

To evaluate the potential effect of the SST on this coefficient, the borate/bicarbonate molar ratios for seawater $\left[\mathrm{B}(\mathrm{OH})_{4}^{-} / \mathrm{HCO}_{3}^{-}\right]_{\text {seawater }}$ were first re-calculated from the measured $\delta^{11} \mathrm{~B}-\mathrm{pH}$ values using the regional SST and then compared to the measured boron/calcium molar ratios
([B/Ca $\left.]_{\text {coral }}\right)$ for all of the corals studied here (Fig. 5). This graph shows that the regional SST strongly controls the partition coefficient $K_{\mathrm{D}}$, which is 0.0057 or less for the highest temperature (in the Marquesas area or Fanning Island during the winter season and the influence of warm and high $\mathrm{pH}$ waters, see below) and 0.0125 for the lowest SST (close to $22.5^{\circ} \mathrm{C}$ in the Red Sea). The $K_{\mathrm{D}}$ values are plotted versus the SST for modern Porites in Figure 6a. This figure shows a strong linear relationship with a regression coefficient $\left(R^{2}\right)$ of 0.99 . This linear dependence confirms that the boron in corals is more easily incorporated in aragonite at low temperatures, as previously observed in Porites (Fallon et al., 2003). 


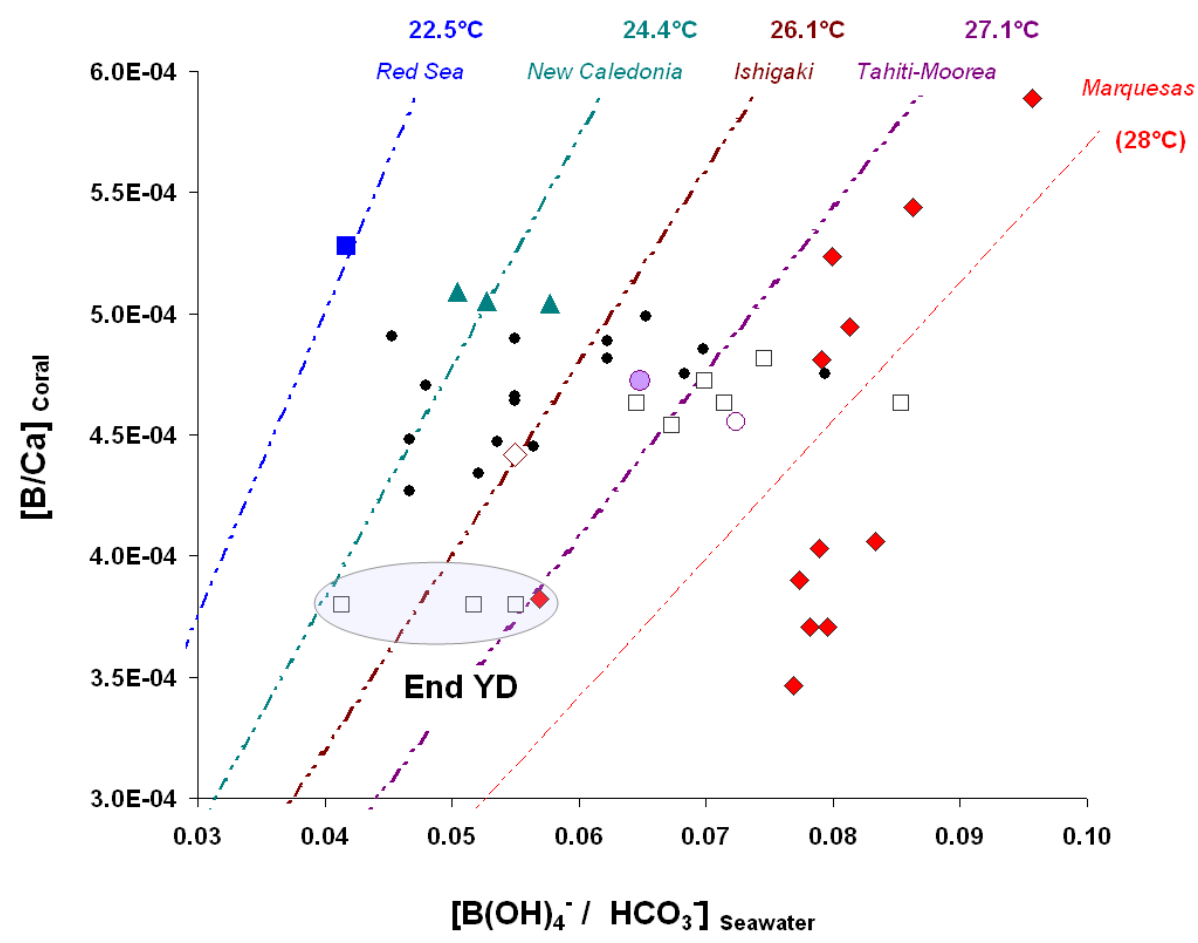

Fig. 5. B/Ca molar ratio in coral plotted against the borate/bicarbonate molar ratio in seawater. Theoretical curves for different partition coefficient $K_{\mathrm{D}}$ values were calculated assuming $T=28^{\circ} \mathrm{C} ; S=35 \%$; $\alpha=0.981$; and $\delta^{11} \mathrm{~B}_{\mathrm{SW}}=39.9 \%$. Regional SSTs was used to calculate the borate/bicarbonate ratios for each of the corals. The temperature strongly influences the partition coefficient $K_{\mathrm{D}}$. Porites near Marquesas showed a $K_{\mathrm{D}}$ of $\sim 0.0057$. The seawater values used to calibrate the partition coefficient were $[\mathrm{B}]_{\text {seawater }}=416 \mu \mathrm{M}$ and $T C \mathrm{CO}_{2}=2 \mathrm{mM}$.

To test whether this linear temperature dependence of $K_{\mathrm{D}}$ applies (i) to ancient aragonite corals near Marquesas and (ii) to a wider temperature range that affects cold-water aragonite corals such as deep sea coral Lophelia pertusa, we extrapolated the regression towards SSTs of $28-29^{\circ} \mathrm{C}$ and temperatures of 5.5 to $11^{\circ} \mathrm{C}$ (Fig. 6b). This low temperature range covers the North Atlantic intermediate waters, which today have $\mathrm{pH}$ values approximately $7.95 \pm 0.05$. For $\mathrm{pH} 7.95$, the $K_{\mathrm{D}}$ deduced from boron concentrations in Lophelia pertusa (Douville et al., 2007) at local temperature agrees with the established regression (Fig. 6b). The average $K_{\mathrm{D}}$ of ancient Marquesas corals was 0.0057 (Fig. 4b). This value fits the linear temperature dependence described above well with deviations of no more than $\pm 1^{\circ} \mathrm{C}$ at $28^{\circ} \mathrm{C}$ (Fig. 5). These reconstructed temperatures match the mean SST observed today near Marquesas. However, the lowest SSTs are estimated at the end of the Younger Dryas (YD) or during the glacial period, and higher SSTs are suggested by Fig. 5 for the Marquesas corals that are about 9 and $14-15 \mathrm{kyr}$ BP old, respectively.

Similar trends are observed for the old Acropora near Tahiti. These corals have a mean $K_{\mathrm{D}}$ of 0.0068 (SST\# $27^{\circ} \mathrm{C}$ ) and a pronounced and unique SST decrease of $2.5^{\circ} \mathrm{C}$ around $11.5 \mathrm{kyr}$ BP ago. Another example of the influence of the SST on the partition coefficient $K_{\mathrm{D}}$ is from the seasonal data published at Fanning Island (Figs. 4a and 5). The seasonal
SSTs in the Fanning Islands vary by $3{ }^{\circ} \mathrm{C}$. The highest temperatures are close to $28^{\circ} \mathrm{C}$ and correspond to surface waters of high $\mathrm{pH}$ recorded by the high density bands of the modern Porites (http://www.nodc.noaa.gov; Hemming et al., 1998; Hönisch et al., 2004). This amplitude of seasonal SST changes matches the temperature $\left(24.5^{\circ} \mathrm{C}-27.5^{\circ} \mathrm{C}\right) \mathrm{de}-$ scribed in Fig. 5. Thus, at Fanning Islands the highest SST of about $27.5^{\circ} \mathrm{C}$ corresponds to a low $K_{\mathrm{D}}$ close to $\sim 0.006$ (Fig. 5), and points close to a high $K_{\mathrm{D}}$ of $\sim 0.0095$ corresponding to $24.5^{\circ} \mathrm{C}$.

\subsection{Variations of " $\delta{ }^{11} \mathrm{~B}-\mathrm{pH}$ " as a function of time}

In fossil Porites from Marquesas (Table 1), the $\delta^{11} \mathrm{~B}$ values vary from 26.0 to $26.6 \%$ o during the Holocene, drastically fall to $24.7 \pm 0.2 \%$ at the end of the Younger Dryas, and then rise again to values between 25.6 and $26.4 \%$ o during the beginning of the Younger Dryas and Bölling Allerød. The highest value $(27.1 \%$ o $)$ was observed during the last glacial period (20.7 kyr BP). During the Holocene, all of the deduced values for the sea surface $\mathrm{pH}$ from Marquesas and Tahiti are similar at $8.23 \pm 0.04$ (Table 1, Fig. 7). These values are equivalent to modern $\mathrm{pH}(\sim 8.15)$ (Fig. 2a) when accounting for the model prediction for anthropogenic acidification on the order of $0.07 \mathrm{pH}$-units (Sabine et al., 2004). At the end of the YD at $\sim 11.5 \mathrm{kyr} B P$, uniformly low $\mathrm{pH}$ values $(\sim 7.99-8.06)$ 

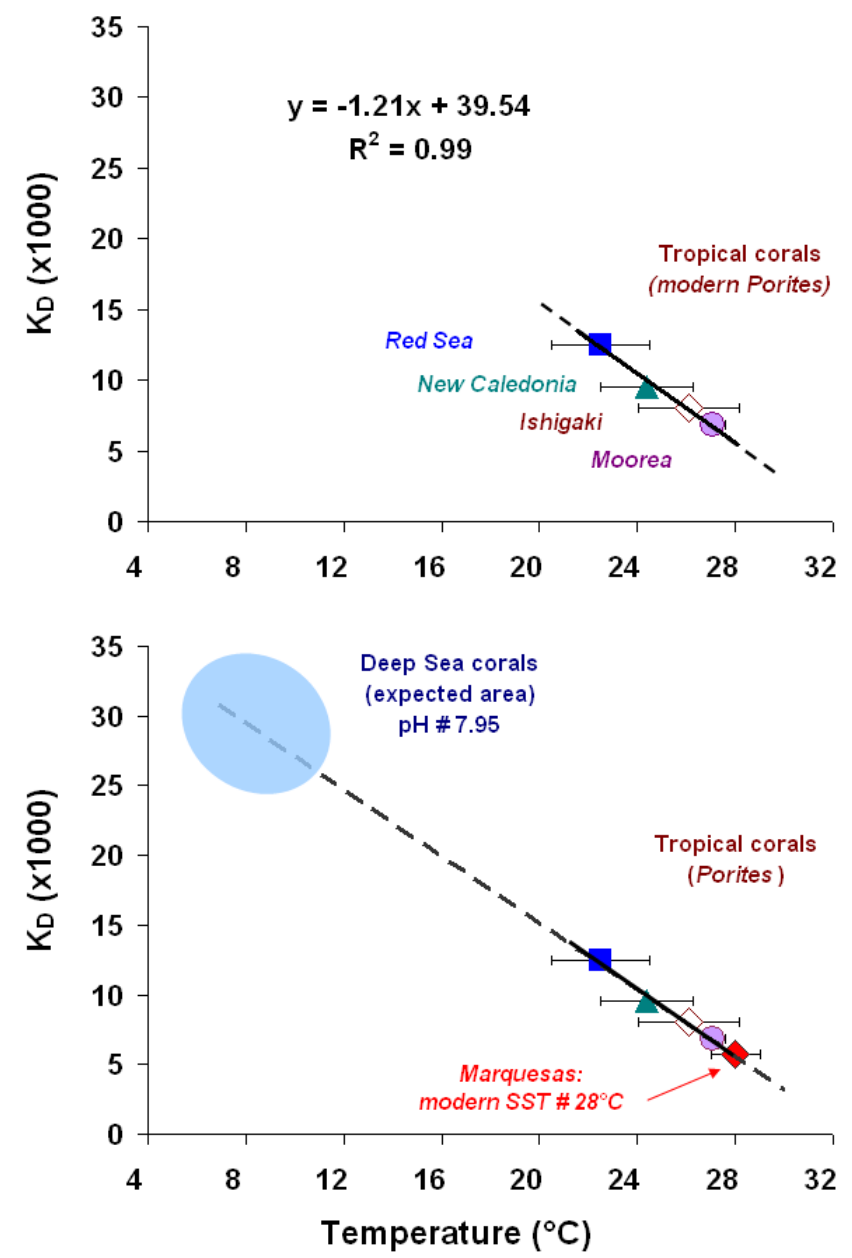

Fig. 6. Linear correlation between the mean regional SST and the partition coefficient $K_{\mathrm{D}}$ obtained from modern Porites samples collected from various SST areas. This regression shows the influence of the temperature on $K_{\mathrm{D}}$ and is valid for various aragonite species. The tropical corals are Porites, Acropora, and the cold sea coral is Lophelia pertusa. The expected area for cold sea corals $\left(6-11^{\circ} \mathrm{C}\right)$ was determined from $\mathrm{pH} 7.95$ and from the high boron concentrations (78-100 ppm) measured in North Atlantic Lophelia pertusa samples collected between $40^{\circ} \mathrm{N}$ and $70^{\circ} \mathrm{N}$ (Douville et al., 2007).

are observed close to both islands (Fig. 7). These low $\mathrm{pH}$ values are preceded by high $\mathrm{pH}$ values (8.14 to 8.30 ) during the Bölling Allerød and the last glacial/interglacial transition (Fig. 7). From foraminifera in the "western" Pacific (ERDC-92), pH reconstruction using the $\delta^{11} \mathrm{~B}$ method yields $\sim 8.23, \sim 8.13$, and $\sim 8.20$ for the early, middle, and late Holocene. During the YD, pH-values were $\sim 8.16$, and during the Bölling Allerød, they were between 8.1 and 8.2. During the last glacial period, the highest $\mathrm{pH}$ values are estimated at $\sim 8.3$ (Palmer and Pearson, 2003). The central equatorial Pacific experienced larger $\mathrm{pH}$ changes $(0.2 \mathrm{pH}$-units) than the western Pacific $(\sim 0.1 \mathrm{pH}$-units $)$ during the transition between the YD and the Holocene. This difference may be attributed to the temporal resolution obtained using corals and foraminifera. In corals, the sampling represents one or two years of growth, while the $1 \mathrm{~cm}$-thick samples in the western Pacific deep-sea sediment core ERDC-92, due to the low sedimentation rate of $1.4 \mathrm{~cm} / \mathrm{kyr}$ (Palmer and Pearson, 2003), include numerous foraminifera covering several hundred years. Bioturbation probably smoothed the amplitude of the $\mathrm{pH}$ variations.

Variations of the sea surface $\mathrm{pH}$ are related to changes in surface water $p \mathrm{CO}_{2}$, which is controlled by the $\mathrm{CO}_{2}$ uptake by surface water through ocean-atmosphere $\mathrm{CO}_{2}$ gas exchange. This gas exchange is modulated by the temperature, wind intensity, photosynthesis, lateral or vertical advection and mixing of different water masses. During the YD, the SSTs were slightly lower than the modern SSTs by $\sim 1^{\circ} \mathrm{C}$ to $\sim 3^{\circ} \mathrm{C}$ in the eastern Pacific (Kienast et al., 2006; Koutavas et al., 2002). These values were either similar (Palmer and Pearson, 2003) or lower by $3{ }^{\circ} \mathrm{C}$ to $4.5^{\circ} \mathrm{C}$ in the western part of the Pacific (Beck et al., 1997; Corrège et al., 2004; Gagan et al., 2004) and lower by $1.5^{\circ} \mathrm{C}$ in the central part at Tahiti (Asami et al., 2009). If the SST dropped by $\sim 3{ }^{\circ} \mathrm{C}\left(25^{\circ} \mathrm{C}\right)$, the calculated $\mathrm{pH}$ would be about 8.07 rather than 8.04 because of the temperature dependence of $p K_{\mathrm{B}}$ (Dickson, 1990). As previously observed and especially for Tahiti (Fig. 5), a change in the SST of $\pm 1-3{ }^{\circ} \mathrm{C}$ has a minimal effect on the calculation of the $\mathrm{pH}$.

This temperature effect cannot account for the calculated change of $\sim 0.2 \mathrm{pH}$-units observed at the transition between the YD and the Holocene. Estimates of the $\mathrm{pH}$ from Porites collected on the Flinders reef system in the southwestern $\mathrm{Pa}$ cific reveal inter-decadal changes of $\sim 0.3 \mathrm{pH}$-units over the past 300 years (Pelejero et al., 2005). These changes were attributed to local effects caused by the large lagoon platform structure of the Flinders reef, the water $p \mathrm{CO}_{2}$ buildup through coral calcification and the renewal rate of lagoon water by the South Equatorial current pulsed by the PDO (Pelejero et al., 2005). In the central equatorial Pacific, the impact of these local effects cannot be completely excluded. However, the probability of detecting the extreme changes of $0.2 \mathrm{pH}$-units from corals collected in the two distant islands Tahiti and Marquesas is low given that the samples only provide information for a few years in the Holocene, which began around $11.5 \mathrm{kyr} \mathrm{BP}$ ago. A recent sea surface $\mathrm{pH}-\delta^{11} \mathrm{~B}$ study at the Fiji Islands showed a slight $\mathrm{pH}$ change because of the PDO (Douville et al., 2009). In addition, all ancient corals during the Holocene and until the last glacial period show relatively stable $\mathrm{pH}$ values close to $8.19-8.23$, and 15 years of recent observations indicate a stable $\Delta p \mathrm{CO}_{2}$ in this area (see below, Fig. 8). These observations indicate major and rapid changes in the Pacific oceanic patterns during the transition between the YD and Holocene.

The estimated $\mathrm{pH}$ drop near Tahiti and Marquesas at the end of the YD could be accounted for by an intensified upwelling and westward advection of cooler eastern water masses to the central Pacific. These eastern water masses 


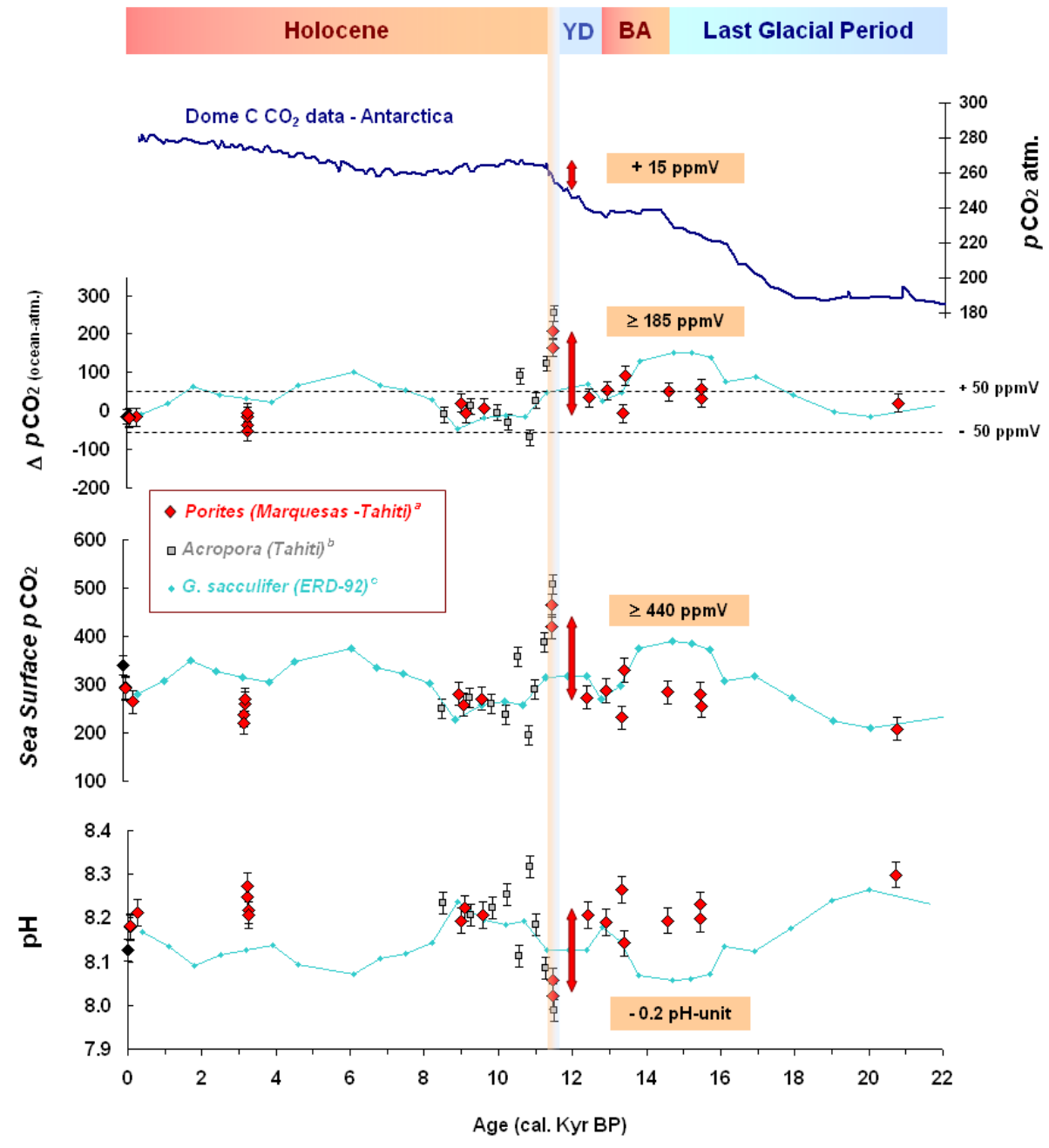

Fig. 7. Comparison of the sub-Equatorial Pacific $\delta^{11} \mathrm{~B}-\mathrm{pH}$ of marine biogenic carbonates over the last 21000 cal yr. Sources are (a) this study; (b) Gaillardet and Allègre, 1995; and (c) Palmer and Pearson, 2003. Filled black diamond: modern Moorea-Tahiti Porites value published by Gaillardet and Allègre (1995). The calculation parameters for the $\mathrm{pH}$ are $\alpha=0.981 ; \delta^{11} \mathrm{~B}_{\mathrm{SW}}=39.9 \%$; $S=35 \%$; and $T=27^{\circ} \mathrm{C}$ for Tahiti (Moorea) and $T=28^{\circ} \mathrm{C}$ for the Marquesas Islands and for ERDC-92. Deduced $\Delta p \mathrm{CO}_{2}$ values (Table 1, see text) and atmospheric $p \mathrm{CO}_{2}$ data (Monnin et al., 2001, 2004) are also plotted to illustrate the synchronization between the abrupt changes to the sea surface $\mathrm{pH}$ and $\Delta p \mathrm{CO}_{2}$ in the central sub-Equatorial Pacific and the atmospheric $\mathrm{CO}_{2}$ increase of $15-20 \mathrm{ppmV}$ at the end of the YD event.

are characterised today by low $\mathrm{pH}$ and also low SST, especially for latitudes between $15^{\circ} \mathrm{S}$ and $20^{\circ} \mathrm{S}$ (Tahiti's latitudes, Fig. 2b). Sustained La Niña-like conditions prevailed at the end of the YD. This interpretation is supported by the presence of a strong east-west SST gradient in the equatorial Pacific around 11500 years ago (Koutavas et al., 2006). The $\mathrm{pH}$ change from 8.04 to 8.23 at the YD-Holocene transition in the Marquesas area indicates a rapid change to more frequent El Niño-like climatic conditions in the equatorial South Pacific. Such changes are also observed in the east-west Pacific SST reconstruction (Koutavas et al., 2006).

\subsection{Estimates of the atmosphere-ocean $\Delta p \mathrm{CO}_{2}$}

In the central sub-equatorial Pacific (Tahiti and Marquesas), twelve Holocene values of $p \mathrm{CO}_{2}$ have an average of about $\sim 250 \pm 30 \mathrm{ppmV}$ for a pH of $8.23 \pm 0.04$ (Table 1). At the end of the $\mathrm{YD}$, the $p \mathrm{CO}_{2}$ estimated for a $\mathrm{pH}$ of 8.04 was $\sim 440 \mathrm{ppmV}$ (SSS: 36.2 ; SST: $28^{\circ} \mathrm{C}$ ) or $\sim 450$ ppmV (SSS: 34.8 ; SST: $25^{\circ} \mathrm{C}$ ) when considering an intensified westward advection of the eastern Pacific water masses of low salinity and temperature. According to the past atmospheric $p \mathrm{CO}_{2}$ from EPICA Dome $\mathrm{C}$ ice cores from Antarctica (Monnin et al., 2001, 2004), the oceanatmosphere $\Delta p \mathrm{CO}_{2}$ differences were between -53 and $+20 \mathrm{ppmV}$ during the Holocene, between +21 and $+91 \mathrm{ppmV}$ before the YD with five pronounced positive values during 


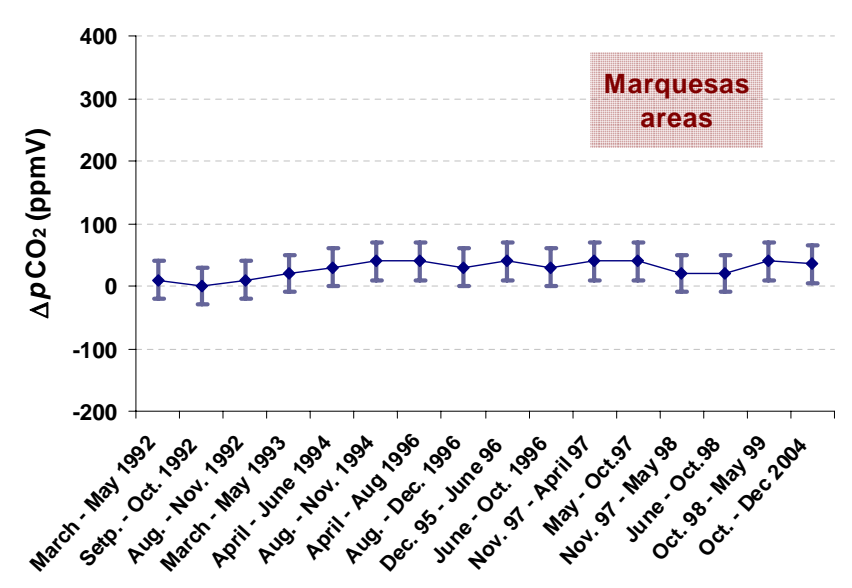

Fig. 8. The relative stability of modern $\Delta p \mathrm{CO}_{2}$ values close to equilibrium in the Tahiti - Marquesas area between $1992 \mathrm{AD}$ and 2004 AD (Dandonneau, 1995; Feely et al., 1999, 2002; Goyet et al., 2009; Goyet and Peltzer, 1997).

the last deglaciation and $+185 \pm 25 \mathrm{ppmV}$ at the end of the YD $\left(p \mathrm{CO}_{2} \mathrm{~atm}=250 \mathrm{ppmV}\right)$. From similar calculations, the $\triangle p \mathrm{CO}_{2}(\sim-15 \mathrm{ppmV})$ for the two modern corals (1950 AD, 1991 AD) from Tahiti (Fig. 7) are close to equilibrium as recently described by Takahashi et al. (2009) for this area. This trend is also in agreement with modern $\Delta p \mathrm{CO}_{2}$ measurements (Fig. 8), which are either close to zero or slightly positive (Dandonneau, 1995; Feely et al., 1999, 2002; Goyet et al., 2009; Goyet and Peltzer, 1997).

Since the early Holocene until today, surface waters in the central sub-equatorial Pacific have mainly served as a moderate sink or source of $\mathrm{CO}_{2}$ for the atmosphere in the vicinity of both Tahiti and the Marquesas Islands (Figs. 7 and 8). Our slight negative or positive $\Delta p \mathrm{CO}_{2}$ values agree with previous suggestions that more frequent El Niño-like oceanographic conditions occurred during the Holocene (Gagan et al., 2004; Koutavas et al., 2006). In contrast, the subequatorial sea surface waters in the central Pacific were a more pronounced source of $\mathrm{CO}_{2}$ to the atmosphere during the last glacial/interglacial transition. This source of $\mathrm{CO}_{2}$ strongly intensified around $11.5 \mathrm{kyr} \mathrm{BP}$ at the end of the YD and quickly reversed during the transition between the YD and the Holocene.

Such feature is connected first to the rapid rise of the atmospheric $p \mathrm{CO}_{2}$ of $\sim 15 \mathrm{ppmV}$ (Fig. 7). This rise was observed quasi-synchronously in the EPICA Dome $\mathrm{C}$ ice core (EDC) (Monnin et al., 2001, 2004) by using refined chronology (Marchitto et al., 2007). Once the chronology of TLD and EDC ice cores is adjusted, this rise is also accompanied by a rapid increase of the atmospheric $\delta^{13} \mathrm{CO}_{2}$ values. This connection was observed in the Taylor Dome ice core (TLD) in Antarctica (Smith et al., 1999) and more recently also in EPICA Dome C (Lourantou et al., 2010). Marchitto et al. (2007) showed that the ${ }^{14} \mathrm{C}$ ages of the intermediate waters in the Eastern Pacific decreased rapidly during
YD-Holocene transition. These authors suggest that the aging of the intermediate waters was caused by northward penetration of the Antarctic Intermediate Water (AAIW) that was greater than the penetration occurring today (Marchitto et al., 2007), and the AAIW had old ${ }^{14} \mathrm{C}$ ages and depleted $\delta^{13} \mathrm{C}$ values. The high $\Delta p \mathrm{CO}_{2}$ at the end of the $\mathrm{YD}$, that was deduced from the $\delta^{11} \mathrm{~B}-\mathrm{pH}$ indicator provides further evidence of the marked changes in the properties of the water masses in the equatorial Pacific and demonstrates the impact of these changes on the atmospheric $\mathrm{CO}_{2}$ content.

\section{Conclusions}

The $\mathrm{pH}$ variations of surface waters in the equatorial Pacific were determined from the isotopic composition of boron in the ancient corals Porites from reefs at Tahiti and Marquesas by MC-ICPMS analyses with an analytical uncertainty of $\pm 0.025 \mathrm{pH}$-units. Our $\delta^{11} \mathrm{~B},[\mathrm{~B}]$ and $\mathrm{pH}$ results obtained with the empirical isotopic fractionation factor close to 0.981 for modern corals agree with previous observations from laboratory calibration experiments. Modern aragonite Porites were sampled from different geographical areas characterized by local SSTs ranging between $22.5^{\circ} \mathrm{C}$ and $27^{\circ} \mathrm{C}$. The results reveal that the temperature strongly controls both the partition constant $K_{\mathrm{D}}$ and the incorporation of boron in Porites but also in various aragonite coral species. More boron is incorporated in the aragonite skeleton at lower SST. The $\delta^{11} \mathrm{~B}$ $\mathrm{pH}$ values were close to $\sim 8.23$ during the Holocene in the surface waters of both Marquesas and the Tahiti Islands. This result is in agreement with the modern or pre-anthropogenic values. The $\delta^{11} \mathrm{~B}-\mathrm{pH}$ values ranged from 8.14 to 8.30 during the last deglaciation, and the highest value measured was at 20.7 kyr BP.

An abrupt $\mathrm{pH}$ drop to $~ 8.04$ was observed at the end of the Younger Dryas around $11.5 \mathrm{kyr} \mathrm{BP}$. The deduced $p \mathrm{CO}_{2}$ values were relatively equilibrated with the atmosphere during the Holocene and the last deglaciation, but during this event, the $p \mathrm{CO}_{2}$ increased to up to $\sim 440 \mathrm{ppmV}$ near both Tahiti and the Marquesas islands. The sea surface waters in the central equatorial Pacific (Tahiti, Marquesas) were a moderate sink or source of $\mathrm{CO}_{2}$ to the atmosphere during the Holocene as today. They were a more important source during the last glacial/interglacial transition, and they were a major source at the end of the YD with a $\Delta p \mathrm{CO}_{2}$ of at least $+185 \mathrm{ppmV}$. This last finding provides further evidence of the marked changes in the properties of the water masses in the equatorial Pacific (Marchitto et al., 2007) and demonstrates the impact of these changes on the atmospheric $\mathrm{CO}_{2}$ content. These results highlight the great potential of the " $\delta{ }^{11} \mathrm{~B}-\mathrm{pH}$ " methodology to precisely reconstruct past oceanic fluxes of $\mathrm{CO}_{2}$ to the atmosphere from well-dated sea surface corals such as Porites and Acropora. 
Acknowledgements. We are greatly indebted to Hélène Isnard and Frédéric Chartier of the CEA laboratory LANIE in Gif /Yvette (France) and Claudia Bouman of the Advanced Mass Spectrometry Laboratory of Thermo Fisher Scientific in Bremen for our fruitful discussions and the use of their instruments during an early stage of the work presented here. We are also grateful to Norbert Frank and Eline Sallé for providing accurate U-series dates for the corals and to Michel Fontugne for constructive discussions. This work received the financial support of the national INSU LEFE/CYBER project PHARE, the Comissariat à l'Energie Atomique (CEA), the French Centre National de la Recherche Scientifique (CNRS) and the Institut de Recherche pour le développement (IRD). Our thanks are extended to John Butscher for his help collecting the modern coral samples in New Caledonia and to the Province Sud of New Caledonia for the permit to collect these corals. We are grateful to David Varillon from IRD "IMAGO", LEGOS laboratory, IRD Nouméa and the French Zonéco program for providing the Thermosalinograph datasets monitored at Uitoe (New Caledonia). Gratitude is expressed to the captain, R. Proner and the crew of the R/V IRD "Alis" for their efficiency during the cruises in Marquesas. The manuscript has greatly improved during the review process by constructive comments made by two anonymous reviewers.

\section{Edited by: S. W. A. Naqvi}

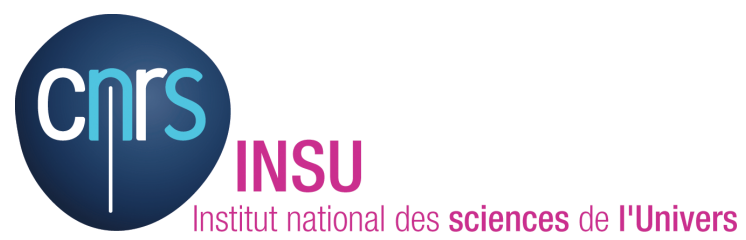

The publication of this article is financed by CNRS-INSU.

\section{References}

Archer, D., Winguth, A., Lea, D., and Mahowald, N.: What caused the Glacial/Interglacial atmospheric $p \mathrm{CO}_{2}$ cycles?, Rev. Geophys., 38(2), 159-189, 2000.

Asami, R., Felis, T., Deschamps, P., Hanawa, K., Iryu, Y., Bard, E., Durand, M., and Murayama, M.: Evidence for tropical South Pacific climate change during the Younger Dryas and the BøllingAllerød from geochemical records of fossil Tahiti corals, Earth Planet. Sc. Lett., 288, 96-107, 2009.

Bard, E., Hamelin, B., Arnold, M., Montaggioni, L., Cabioch, G., Faure, G., and Rougerie, F.: Deglacial sea-level record from Tahiti corals and the timing of global melt water discharge, Nature, 382, 241-244, 1996.

Beck, J. W., Récy, J., Taylor, F., Edwards, R. L., and Cabioch, G.: Abrupt changes in early Holocene tropical sea surface temperature derived from coral records, Nature, 385, 705-707, 1997.

Boiseau, M.: Etude de la variabilité climatique liée à l'ENSO dans l'Océan Pacifique Central Sud (Moorea) à partir de traceurs géochimiques contenus dans le squelette d'un Scleractiniaire à zooxanthelles (Porites Lutea), pH'D thesis, University of Paris VII, Paris, 202 pp., 1998.
Cabioch, G., Montaggioni, L., Frank, N., Seard, C., Sallé, E., Payri, C., Pelletier, B., and Paterne, M.: Successive reef depositional events along the Marquesas foreslopes (French Polynesia) since 26 ka, Mar. Geol., 254, 18-34, 2008.

Caldeira, K. and Wickett, M. E.: Anthropogenic carbon and ocean pH, Nature, 425, 365, 2003.

Corrège, T., Gagan, M. K., Beck, J. W., Burr, G. S., Cabioch, G., and Le Cornec, F.: Interdecadal variation in the extent of South Pacific tropical waters during the Younger Dryas event, Nature, 428, 927-929, 2004.

Dandonneau, Y.: Sea-surface partial pressure of carbon dioxide in the eastern equatorial Pacific (August 1991 to October 1992): A multivariate analysis of physical and biological factors, DeepSea Res. Pt. II, 42(2-3), 349-364, 1995.

Delcroix, T., Henin, C., Porte, V., and Arkin, P.: Precipitation and sea surface salinity in the tropical Pacific Ocean, Deep-Sea Res. Pt. I, 73(7), 1123-1141, 1996.

Dickson, A. G., Sabine, C. L., and Christian, J. R.: Guide to best practices for ocean $\mathrm{CO}_{2}$ measurements, PICES Special Publication 3, 191 pp., 2007.

Dickson, A. G.: Thermodynamic of the dissociation of boric acid in synthetic seawater from 273.15 to 318.15 K, Deep-Sea Res., 37, 755-766, 1990.

Douville, E., Juillet-Leclerc, A., Cabioch, G., Louvat, P., Gaillardet, J., Gehlen, M., Bopp, L., and Paterne, M.: Boron isotopes in Fiji corals and precise ocean acidification reconstruction, AGU Fall Meeting, San Francisco, California, USA, 14-18 December 2009, GC24A-04, 2009.

Douville, E., Copard, K., Colin, C., and Frank, N.: Major and trace elements in deep sea corals Lophelia pertusa from the eastern North Atlantic, ICP-9, Shanghai, China, 3-7 September 2007, P1-28, 45, 2007.

Fallon, S. J., McCulloch, M. T., and Alibert, C.: Examining water temperature proxies in Porites corals from the Great Barrier Reef: a cross-shelf comparison, Coral Reefs, 22, 389-404, 2003.

Feely, R. A., Boutin, J., Cosca, C. E., Dandonneau, Y., Etcheto, J., Inoue, H. Y., Ishii, M., Le Quéré, C., Mackey, D. J., McPhaden, M., Metzl, N., Poisson, A., and Wanninkhof, R.: Seasonal and interannual variability of $\mathrm{CO}_{2}$ in the equatorial Pacific, DeepSea Res. Pt. II, 49, 2443-2449, 2002.

Feely, R. A., Wanninkhof, R., Takahashi, T., and Tans, P.: Influence of El Niño on the equatorial Pacific contribution to atmospheric $\mathrm{CO}_{2}$ accumulation, Nature, 398, 597-601, 1999.

Foster, G. L.: Seawater $\mathrm{pH}, p \mathrm{CO}_{2}$ and $\left[\mathrm{CO}_{3}^{2-}\right]$ variations in the Caribbean Sea over the last $130 \mathrm{kyr}$ : A boron isotope and $\mathrm{B} / \mathrm{Ca}$ study of planktic foraminifera, Earth Planet. Sc. Lett., 271, 254 266, 2008.

Gagan, M. K., Hendy, E. J., Haberle, S. G., and Hantoro, W. S.: Post-glacial evolution of the Indo-Pacific Warm Pool and El Niño-Southern oscillation, Quatern. Int., 118-119, 127-143, 2004.

Gaillardet, J. and Allègre, C. J.: Boron isotopic compositions of corals: seawater or diagenesis record?, Earth Planet. Sc. Lett., 136, 665-676, 1995.

Gertman, I. and Brenner, S.: Analysis of water temperature variability in the Gulf of Eilat, Report of Israel Oceanogr. Limnol. Res., 13 pp., 2004.

Goyet, C., Ito Gonçalves, R., and Touratier, F.: Anthropogenic carbon distribution in the eastern South Pacific Ocean, 
Biogeosciences, 6, 149-156, doi:10.5194/bg-6-149-2009, 2009.

Goyet, C. and Peltzer, E. T.: Variation of $\mathrm{CO}_{2}$ partial pressure in surface seawater in the equatorial Pacific Ocean, Deep-Sea Res. Pt. I, 44(9-10), 1611-1625, 1997.

Heiss, G. A., Dullo, W. C., Joachimski, M. M., Reijmer, J. J. G., and Schumacher, H.: Increased Seasonality in the Gulf of Aqaba, Red Sea, Recorded in the Oxygen Isotope Record of a Porites lutea Coral, Senck. Marit., 30, 17-26, 1999.

Hemming, N. G., Guilderson, T. P., and Fairbanks, R. G.: Seasonal variations in the boron isotopic composition of coral: A productivity signal?, Global Biogeochem. Cy., 12(4), 581-586, 1998.

Hemming, N. G. and Hanson, G. N.: Boron isotopic composition and concentration in modern marine carbonates, Geochim. Cosmochim. Ac., 56, 537-543, 1992.

Hemming, N. G., Reeder, R. J., and Hanson, G. N.: Mineral-fluid partitioning and isotopic fractionation of boron in synthetic calcium carbonate, Geochim. Cosmochim. Ac., 59(2), 371-379, 1995.

Henin, C.: Surveillance Thermohaline de la ZEE en 1997 et 1998, Zoneco Report, IRD, Noumea, New Caledonia, 16 pp., 1999.

Henin, C. and Cresswell, G. R.: Upwelling along the western barrier reef of New Caledonia, Mar. Freshwater Res., 56(7), 1005-1010, 2005.

Hönisch, B. and Hemming, N. G.: Surface ocean $\mathrm{pH}$ response to variations in $p \mathrm{CO}_{2}$ through two full glacial cycles, Earth Planet. Sc. Lett., 236, 305-314, 2005.

Hönisch, B., Hemming, N. G., Archer, D., Siddall, M., and McManus, J. F.: Atmospheric Carbon Dioxide Concentration Across the Mid-Pleistocene Transition, Science, 324, 15511554, 2009.

Hönisch, B., Hemming, N. G., Grottoli, A. G., Amat, A., Hanson, G. N., and Bijma, J.: Assessing scleractinian corals as recoders for paleo-pH: Empirical calibration and vital effects, Geochim. Cosmochim. Ac., 68(18), 3675-3685, 2004.

Hönisch, B., Hemming, N. G., and Loose, B.: Comment on "A critical evaluation of the boron isotope-pH proxy: The accuracy of ancient ocean pH estimates" by Pagani, M., Lemarchand, D., Spivack, A., and Gaillardet, J., Geochim. Cosmochim. Ac., 71, 1636-1641, 2007.

Inoue, H. Y., Ishii, M., Matsueda, H., Saito, S., Aoyama, M., Tokieda, T., Midorikawa, T., Nemoto, K., Kawano, T., Asanuma, I., Ando, K., Yano, T., and Murata, A.: Distributions and variations in the partial pressure of $\mathrm{CO}_{2}$ in surface waters $\left(p \mathrm{CO}_{2 \mathrm{w}}\right)$ of the central and western equatorial Pacific during the 1997/1998 El Niño event, Mar. Chem., 76(1-2), 59-75, 2001.

Inoue, M., Nohara, M., Okai, T., Suzuki, A., and Kawahata, H.: Concentrations of Trace Elements in Carbonate Reference Materials Coral JCp-1 and Giant Clam JCt-1 by Inductively Coupled Plasma-Mass Spectrometry, Geostand. Geoanal. Res., 28(3), 411-416, 2004.

IPCC: Carbon dioxide Capture and Storage, Intergovernmental Panel on Climate Change Special Report, edited by: Metz, B., de Coninck, O. D. H., Loos, M., and Meyer, L., 2005.

Kakihana, H., Kotoka, M., Satoh, S., Nomura, M., and Okamoto, M.: Fundamental studies on the ion-exchange separation of boron isotopes, B. Chem. Soc. Jpn., 50, 158-163, 1977.

Kienast, M., Kienast, S. S., Calvert, S. E., Eglinton, T. I., Mollenhauer, G., François, R., and Mix, A. C.: Eastern Pacific cooling and Atlantic overturning circulation during the last deglaciation,
Nature, 443, 846-849, 2006.

Klochko, K., Kaufman, A. J., Yao, W., Byrne, R. H., and Tossell, J. A.: Experimental measurement of boron isotope fractionation in seawater, Earth Planet. Sc. Lett., 248, 276-285, 2006.

Kohfeld, K. E., Le Quere, C., Harrison, S. P., and Anderson, R. F.: Role of marine biology in glacial-interglacial $\mathrm{CO}_{2}$ cycles, Science, 38, 74-78, 2005.

Koutavas, A., deMenocal, P. B., Olive, G. C., and Lynch-Stieglitz, J.: Mid-Holocene El Niño-Southern Oscillation (ENSO) attenuation revealed by individual foraminifera in eastern tropical $\mathrm{Pa}$ cific sediments, Geology, 34(12), 993-996, 2006.

Koutavas, A., Lynch-Stieglitz, J., Marchitto, T. M., and Sachs, J. P.: El Niño-like pattern in ice age tropical Pacific sea surface temperature, Science, 297, 226-230, 2002.

Le Quéré, C., Rödenbeck, C., Buitenhuis, E. T., Langenfelds, R., Gomez, A., Labuschagne, C., Ramonet, M., Nakazawa, T., Metzl, N., Gillett, N., and Heimann, M.: Saturation of the Southern Ocean $\mathrm{CO}_{2}$ sink due to recent climate change, Science, 316, 1735-1738, doi:10.1126/science.1136188, 2007.

Lécuyer, C., Grandjean, P., Reynard, B., Albarède, F., and Telouk, P.: ${ }^{11} \mathrm{~B} /{ }^{10} \mathrm{~B}$ analysis of geological materials by ICP-MS Plasma 54: Application to the boron fractionation between brachiopod calcite and seawater, Chem. Geol., 186, 45-55, 2002.

Lefèvre, N., Andrié, C., Dandonneau, Y., Reverdin, G., and Rodier, M.: $p \mathrm{CO}_{2}$, chemical properties, and estimated new production in the equatorial Pacific in January-March 1991, J. Geophys. Res., 99, 12639-12654, 1994.

Liu, Y., Liu, W., Peng, Z., Xiao, Y., Wei, G., Sun, W., He, J., Liu, G., and Chou, C. L.: Instability of seawater $\mathrm{pH}$ in the South China Sea during the mid-late Holocene: Evidence from boron isotopic composition of corals, Geochim. Cosmochim. Ac., 73, 1264-1272, 2009.

Lourantou, A., Lavric, J. V., Köhler, P., Barnola, J. M., Paillard, D., Michel, E., Raynaud, D., and Chappellaz, J.: Constraint of the $\mathrm{CO}_{2}$ rise by new atmospheric carbon isotopic measurements during the last deglaciation, Global Biogeochem. Cy., 24, GB2015, doi:10.1029/2009GB003545, 2010.

Louvat, P., Bouchez, J., and Paris, G.: MC-ICP-MS isotope measurements with direct injection nebulization (d-DIHEN): optimization and application to boron in seawater and carbonate samples, Geostand. Geoanal. Res., in press, 2010.

Lueker, T. J., Dickson, A. G., and Keeling, C. D.: Ocean $p \mathrm{CO}_{2}$ calculated from dissolved inorganic carbon, alkalinity, and equations for $K_{1}$ and $K_{2}$ : validation based on laboratory measurements of $\mathrm{CO}_{2}$ in gas and seawater at equilibrium, Mar. Chem., 70, 105-119, 2000.

Marchitto, T. M., Lehman, S. J., Ortiz, J. D., Flückiger, J., and vanGeen, A.: Marine radiocarbon evidence for the mechanism of deglacial atmospheric $\mathrm{CO}_{2}$ rise, Science, 316, 1456-1459, 2007.

McGillicuddy, D. J., Anderson, L. A., Bates, N. R., Bibby, T., Buesseler, K. O., Carlson, C. A., Davis, C. S., Ewart, C., Falkowski, P. G., Goldthwait, S. A., Hansell, D. A., Jenkins, W. J., Johnson, R., Kosnyrev, V. K., Ledwell, J. R., Li, Q. P., Siegel, D. A., and Steinberg, D. K.: Eddy/wind interactions stimulate extraordinary mid-ocean plankton blooms, Science, 316, 1021-1026, 2007.

Millero, F. J.: Thermodynamics of the carbon dioxide system in the oceans, Geochim. Cosmochim. Ac., 59, 661-677, 1995.

Monnin, E., Indermühle, A., Dällenbach, A., Flückiger, J., Stauffer, B., Stocker, T. F., Raynaud, D., and Barnola, J. M.: Atmospheric 
$\mathrm{CO}_{2}$ concentrations over the last glacial termination, Science, 291, 112-114, 2001.

Monnin, E., Steig, E. J., Siegenthaler, U., Kawamura, K., Schwander, J., Stauffer, B., Stocker, T. F., Morse, D. L., Barnola, J. M., Bellier, B., Raynaud, D., and Fischer, H.: Evidence for substantial accumulation rate variability in Antarctica during the Holocene, through synchronization of $\mathrm{CO}_{2}$ in the Taylor Dome, Dome C and DML ice cores, Earth Planet. Sc. Lett., 224, 45-54, 2004.

Orr, J. C., Fabry, V. J., Aumont, O., Bopp, L., Doney, S. C., Feely, R. A., Gnanadesikan, A., Gruber, N., Ishida, A., Joos, F., Key, R. M., Lindsay, K., Maier-Reimer, E., Matear, R., Monfray, P., Mouchet, A., Najjar, R. G., Plattner, G. K., Rodgers, K. B., Sabine, C. L., Sarmiento, J. L., Schlitzer, R., Slater, R. D., Totterdell, I. J., Weirig, M. F., Yamanaka, Y., and Yool, A.: Anthropogenic ocean acidification over the twenty-first century and its impact on calcifying organisms, Nature, 437, 681-686, 2005.

Pagani, M., Lemarchand, M. D., Spivack, A., and Gaillardet, J.: A critical evaluation of the boron isotope-pH proxy: The accuracy of ancient ocean $\mathrm{pH}$ estimates, Geochim. Cosmochim. Ac., 69(4), 953-961, 2005.

Palmer, M. R. and Pearson, P. N.: A 23 000-Year record of surface water $\mathrm{pH}$ and $p \mathrm{CO}_{2}$ in the Western Equatorial Pacific Ocean, Science, 300, 480-482, 2003.

Paterne, M., Ayliffe, L. K., Arnorld, M., Cabioch, G., TisnératLaborde, N., Hatté, C., Douville, E., and Bard, E.: Paired ${ }^{14} \mathrm{C}$ and ${ }^{230}$ Th dating of surface corals from the Marquesas and Vanuatu (Sub-Equatorail Pacific) in the 3000 to 15000 cal yr interval, Radiocarbon, 46(2), 551-566, 2004.

Pelejero, C., Calco, E., McCullogh, M. T., Marshall, J. F., Gagan, M. K., Lough, J. M., and Opdyke, B. N.: Preindustrial to Modern interdecadal variability in Coral Reef pH, Science, 309, 22042207, 2005.

Petit, J. R., Jouzel, J., Raynaud, D., Barkov, N. I., Barnola, J.-M., Basile, I., Benders, M., Chappellaz, J., Davis, M., Delayque, G., Delmotte, M., Kotlyakov, V. M., Legrand, M., Lipenkov, V. Y., Lorius, C., Pépin, L., Ritz, C., Saltzman, E., and Stievenard, M.: Climate and atmospheric history of the past 420,000 years from the Vostok ice core, Antarctica, Nature, 399, 429-436, 1999.

Reynaud, S., Hemming, N. G., Juillet-Leclerc, A., and Gattuso, J. P.: Effect of $p \mathrm{CO}_{2}$ and temperature on the boron isotopic composition of the zooxanthellate coral Acropora sp., Coral Reefs, 23, 539-546, 2004.

Sabine, C. L., Feely, R. A., Gruber, N., Key, R. M., Lee, K., Bullister, J. L., Wanninkhof, R., Wong, C. S., Wallace, D. W. R., Tilbrook, B., Millero, F. J., Peng, T. H., Kozyr, A., Ono, T., and Rios, A. F.: The Oceanic Sink for Anthropogenic $\mathrm{CO}_{2}$, Science, 305, 367-371, 2004.

Sanchez-Valle, C., Reynard, B., Daniel, I., Lécuyer, C., Martinez, I., and Chervin, J. C.: Boron isotopic fractionation between minerals and fluids: new insights from in situ high pressurehigh-temperature vibrational spectroscopic data, Geochim. Cosmochim. Ac., 69, 4301-4313, 2005.
Sanyal, A., Hemming, N. G., Broecker, W. S., Lea, D. W., Spero, H. J., and Hanson, G. N.: Oceanic pH control on the boron isotopic composition of foraminifera: Evidence from culture experiments, Paleoceanography, 11(5), 513-517, 1996.

Sanyal, A., Nugent, M., Reeder, R. J., and Bijma, J.: Seawater pH control on the boron isotopic composition of calcite: Evidence from inorganic calcite precipitation experiments, Geochim. Cosmochim. Ac., 64(9), 1551-1555, 2000.

Sigman, D. M. and Boyle, E. A.: Glacial/interglacial variations in atmospheric carbon dioxide, Nature, 407, 859-869, 2000.

Smith, H. J., Fischer, H., Wahlen, M., Mastroianni, D., and Deck, B.: Dual modes of the carbon cycle since the Last Glacial Maximum, Nature, 400, 248-250, 1999.

Spivack, A. J., You, C. F., and Smith, H. J.: Foraminiferal boron isotope ratios as a proxy for surface ocean $\mathrm{pH}$ over the past $21 \mathrm{Myr}$, Nature, 363, 149-151, 1993.

Taft, B. A. and Kessler, W. S.: Variations of zonal currents in the central tropical Pacific during 1970 to 1987: sea-level and dynamic height measurements, J. Geophys. Res., 96, 12599-12618, 1991.

Takahashi, T., Sutherland, S. C., Wanninkhof, R., Sweeney, C., Feely, R. A., Chipman, D. W., Hales, B., Friederich, G., Chavez, F., Watson, A., Bakker, D. C. E., Schuster, U., Metzl, N., Yoshikawa-Inoue, H., Ishii, M., Midorikawa, T., Nojiri, Y., Sabine, C., Olafsson, J., Arnarson, T. S., Tilbrook, B., Johannessen, T., Olsen, A., Bellerby, R., Körtzinger, A., Steinhoff, T., Hoppema, M., de Baar, H. J. W., Wong, C. S., Delille, B., and Bates, N. R.: Climatological mean and decadal changes in surface ocean $p \mathrm{CO}_{2}$, and net sea-air $\mathrm{CO}_{2}$ flux over the global oceans, Deep-Sea Res. Pt. II, 56, 554-577, 2009.

Vengosh, A., Kolodny, Y., Starinsky, A., Chivas, A. R., and McCul$\operatorname{logh}$, M. T.: Coprecipitation and isotopic fractionation of boron in modern biogenic carbonates, Geochim. Cosmochim. Ac., 55, 2901-2910, 1991.

Wei, G., McCulloch, M. T., Mortimer, G., Deng, W., and Xie, L.: Evidence for ocean acidification in the Great Barrier Reef of Australia, Geochim. Cosmochim. Ac., 73, 2332-2346, 2009.

Weiss, R. F.: Carbon dioxide in water and seawater: the solubility of a non-ideal gas, Mar. Chem., 2, 203-215, 1974.

Xiao, Y. K., Shirodkar, P. V., Zhang, C. G., Wei, H. Z., Liu, W. G., and Zhou, W. J.: Isotopic fractionation of boron in growing corals and its palaeoenvironmental implication, Curr. Sci. India, 90(3), 414-420, 2006.

Yu, J., Elderfield, H., and Hönisch B.: B/Ca in planktonic foraminifera as a proxy for surface seawater $\mathrm{pH}$, Paleoceanography, 22, PA2202, doi:10.1029/2006PA001347, 2007.

Zeebe, R. E.: Stable boron isotope fractionation between dissolved $\mathrm{B}(\mathrm{OH})_{3}$ and $\mathrm{B}(\mathrm{OH})_{4}^{-}$, Geochim. Cosmochim. Ac., 69(11), 2753-2766, 2005. 